\title{
Rifting, subduction and collisional records from pluton petrogenesis and geochronology in the Hindu Kush, NW Pakistan
}

\author{
Shah Faisal ${ }^{1,2^{*}}$, Kyle P. Larson ${ }^{1}$, Jess King ${ }^{3}$, John M. Cottle ${ }^{4}$ \\ ${ }^{1}$ Earth and Environmental Sciences, IKBAS, University of British Columbia, Okanagan, \\ 3247 University Way, Kelowna, BC VIV 1V7, Canada \\ ${ }^{2}$ National Centre of Excellence in Geology, University of Peshawar, Peshawar-25120 KPK, \\ Pakistan \\ ${ }^{3}$ Department of Earth Science, The University of Hong Kong \\ ${ }^{4}$ Department of Earth Science University of California, Santa Barbara, CA 93106-9630, USA \\ * Corresponding Author, \\ E-mail address: shahfaisal@upesh.edu.pk
}




\section{Abstract:}

New U-(Th)/Pb geochronology and geochemical analyses of plutonic bodies in the Hindu Kush range, NW Pakistan, provide insight on the crustal growth and tectonic evolution of the southern Eurasian margin. These new data outline a protracted magmatic history that spans the Cambrian to the Neogene (ca. 538 to $23 \mathrm{Ma}$ ) and record a variety of petrogenetic associations variably influenced by within plate, volcanic arc, and collision tectonic environments. The Kafiristan pluton ( $538 \pm 4$ to $487 \pm 3 \mathrm{Ma}$ ) yields geochemical signatures consistent with extensional plutonism and rifting of the Hindu Kush terrane from Gondwana. The Tirich Mir (127 \pm 1 to $123 \pm 1 \mathrm{Ma})$ and Buni-Zom (110 \pm 1 to $104 \pm 1 \mathrm{Ma})$ plutons have geochemical signatures that can be attributed to a subduction related continental volcanic arc system that developed along the southern margin of Eurasia in the Mesozoic. The Garam Chasma pluton, the youngest body in the study area $(27.3 \pm 0.5$ to $22.8 \pm 0.4 \mathrm{Ma})$, yields a geochemical signature consistent with widespread anatexis during crustal thickening related to the development of the Himalaya. The present geochemical and geochronological analysis from the Hindu Kush have produced important new constraints on the timing of tectonic events and variable tectonic settings along the south Eurasian margin before and after the continued India-Asia collision.

Key words: Hindu Kush, Eurasia, pluton petrogenesis, geochemistry, U-(Th)/Pb geochronology, tectonomagmatic evolution, Himalayan orogenic history.

\section{INTRODUCTION}

The NE-SW trending Hindu Kush range stretches for more than $600 \mathrm{~km}$ from northwestern Pakistan into adjacent Afghanistan (Figs. 1 and 2). The geology of the range 
records a complex history of magmatism, deformation, and metamorphism spanning the early Paleozoic to the present day (Debon et al., 1987; Hildebrand, 1998; Zanchi and Gaetani, 2011; Faisal et al., 2014). Because the Hindu Kush records evidence of the evolution of Eurasia prior to continental collision (Zanchi et al., 2000; Hildebrand et al., 2001; Zanchi and Gaetani, 2011; Faisal et al., 2014), which is not well preserved in other parts of the orogen, the geologic history of the Hindu Kush is important for our understanding of the tectonic, magmatic and metamorphic evolution of the southern Eurasian margin.

The Hindu Kush terrane, which comprises most of the study area, was detached from Gondwana in the Paleozoic (Zanchi and Gaetani, 2011; Angiolini et al., 2013) and accreted to the southern margin of Eurasia in the Late Triassic (Faisal et al., 2014). Its accretion was followed closely by the collision and accretion of the Karakoram terrane in the Early Jurassic (Zanchi et al., 2000; Faisal et al., 2014). Continued northward subduction of the Paleotethys from the Middle Jurassic to the Early Cretaceous along the southern margin of Eurasia resulted in the intrusion of plutonic bodies in the Tirich Mir-Wakhan and Karakoram belts in an Andean-style margin (Searle et al., 1989, Hildebrand et al., 2001; Searle et al., 2010). The Kohistan island arc is interpreted to have developed within the Paleotethys sometime in the Mesozoic above a northward-dipping subduction zone (Tahirkheli et al., 1979) and was accreted to Eurasia in the Late Cretaceous (Petterson et al., 1991; Fraser et al., 2001; Faisal et al., 2014). Continued subduction thereafter resulted in the development of a second Andeanstyle margin marked by the intrusion of the Kohistan Batholith (Petterson and Windley, 1991). Ultimately, the Kohistan island arc was sandwiched between India and Eurasia during the Cenozoic initiation of their collision (Beck et al., 1995). 
While timing constraints on accretion events and metamorphism now exist for the Hindu Kush (Zanchi et al., 2000; Hildebrand et al., 2001; Heuberger et al., 2007; Faisal et al., 2014) relatively little is known about the various plutonic bodies that intrude the region. There have been no systematic geochemical studies of the plutons of the Pakistani Hindu Kush, and therefore, the geochemical characteristics, potential sources, and the tectonic evolution of the Kafiristan, Tirich Mir, Buni-Zom (exposed along Golen Gol) and Garam Chasma plutonic bodies (Fig. 2) remain poorly constrained. Their occurrence has been variably attributed to subduction and/or collision-related crustal thickening processes (e.g. Desio, 1964; Debon et al., 1987; Hildebrand 1998, Hildebrand et al., 2000; Hildebrand et al., 2001; Zafar et al., 2000; Zanchi et al., 2000; Heubergar et al., 2007). This study examines the petrogenesis and tectonic significance of the Kafiristan, Tirich Mir, Buni-Zom and Garam Chasma plutons based on new major, trace and rare earth element (REE) data and integrated $\mathrm{U}(\mathrm{Th}) \mathrm{Pb}$ (zircon/monazite) geochronology. This work contributes to the record of major tectonic events in the Hindu Kush and helps improve our understanding of the evolution of the southern margin of Eurasia, subduction dynamics of the Tethys, and the evolution of the Himalaya-Karakoram-Tibetan orogenic system.

\subsection{Background Geology and Existing Chronology}

The present work is focused on the Hindu Kush in the Chitral region, NW Pakistan (Fig. 1). The geology of the area is characterized by multiply deformed, variably metamorphosed, Paleozoic to Mesozoic sedimentary rocks intruded by the elongate Kafiristan, Tirich Mir, Buni-Zom, Kesu-Kohuzi and Garam Chasma plutons (Calkins et al., 1981; Hildebrand et al., 2000; Fig. 2). The plutonic bodies typically form physiographic 
peaks in the region, which reach elevations of $7700+\mathrm{m}$ locally.

Published constraints on the age of plutonic rocks in the Hindu Kush vary considerably. Existing whole rock $\mathrm{Rb}-\mathrm{Sr}$ data from the Kafiristan and Tirich Mir plutons outline ages of $483 \pm 21 \mathrm{Ma}$ (Debon et al., 1987) and $115 \pm 4 \mathrm{Ma}$ (Desio, 1964) respectively. $\mathrm{U}-\mathrm{Pb}$ Isotope Dilution Thermal Ionization Mass Spectrometry (ID-TIMS) analysis on monazite and uraninite grains from a pegmatite dyke in the Tirich Mir fault zone, thought to be related to the main Tirich Mir plutonic body, yielded a discordant, interpreted intrusion age of $114 \pm 2$ Ma (Hildebrand et al., 2000). More recently, zircon grains analyzed from a different specimen of the Tirich Mir body yielded two concordant analyses interpreted to comprise an age of $121 \pm 1 \mathrm{Ma}$ (Heuberger et al. 2007). Both U-Pb age estimates for the Tirich Mir pluton are consistent with a $110.6 \pm 3.2$ Ma post-magmatic ${ }^{39} \mathrm{Ar}-{ }^{40} \mathrm{Ar}$ (muscovite) date (Heuberger et al., 2007). A specimen of the Buni-Zom plutonic body collected to the northeast of study area yielded a U-Pb (zircon; ID-TIMS) age of 103.79 $\pm 0.27 \mathrm{Ma}$ defined by two concordant data points (Heuberger et al., 2007). Finally, U-Pb ID-TIMS analyses on monazite and xenotime grains from a specimen collected from the Garam Chasma pluton yielded a discordant age of $24 \pm 0.5 \mathrm{Ma}$ (Hildebrand et al. 1998). This is consistent with 18$20 \mathrm{Ma} \mathrm{K}-\mathrm{Ar}$ (biotite) dates from the same body if they are interpreted to represent cooling and not crystallization (Zafar et al., 2000).

\section{PLUTON DESCRIPTIONS}

Plutonic rocks are a major constituent of the eastern Hindu Kush comprising $\sim 35 \%$ of the bedrock in the region (Fig. 1). The grayish white (fresh) Kafiristan pluton exposed along the Bomborate and Rumboor valleys (Fig. 1) is foliated and is characterized by a porphyritic 
texture with K-feldspar megacrysts ranging in size from 3-4 cm. The matrix minerals consist of $\mathrm{Qz}+\mathrm{Kfs}+\mathrm{Pl}+\mathrm{Bt} \pm \mathrm{Hbl}$ and accessory Zrn + Tur $+\mathrm{Ap}+\mathrm{Ep}$ (Fig. 3A and B). The alkali feldspar and plagioclase locally display perthitiic and myrmetic textures respectively. Minor sericitization is observed in one specimen of the Kafiristan pluton (S60; Fig. 1). Initial petrographic observation indicates the pluton includes at least two phases; a $\mathrm{Bt}+\mathrm{Hbl}$ bearing phase along the Bomborate valley and a $\mathrm{Hbl}$ free phase exposed along the Rumboor valley (Fig. 1).

The grayish white and pinkish (fresh) Tirich Mir pluton is foliated and porphyritic with K-feldspar megacrysts ranging in size from 4-5 cm. The Tirich Mir intrusive has abundant Qz + Kfs + Pl + Bt + Ms, \pm Grt, and accessory Zrn + Ap (Fig. 3C and D). Hbl has been reported from Tirich Mir pluton (Searle et al., 2001), but it was not observed in this study. Perthite, myrmekite, and zoned Pl are common locally. Petrographically, the Tirich Mir pluton can be divided into at least three phases (1) Ms $+\mathrm{Bt}$ (2), Ms $+\mathrm{Bt}+\mathrm{Grt}$, and (3) Ms + Tur.

Previous studies have mapped the Buni-Zom and Kesu Kohuzi plutons as separate bodies (e.g. Aslam et al., 2007). Fieldwork in the Golen Gol area during this study, however, shows that the Buni-Zom pluton extends much farther southwest than previously thought, almost to the Kesu Kohuzi body. In this study the Buni-Zom and Kesu Kohuzi are considered as part of the same plutonic body (Fig. 1). For simplicity, they are collectively referred to as 'Buni-Zom' here forward. The dark gray to white (fresh) Buni-Zom plutonic body, which crops out along the Golen Gol, consists of Afs $+\mathrm{Pl}+\mathrm{Hbl}+$ Bt with accessory Ttn, Zrn, Ap and opaques (Fig. 3E and F). Plagioclase crystals are generally zoned and perthitic textures are observed in alkali feldspar locally. Petrographically, the Buni-Zom pluton can be divided 
into two phases: (1) biotite + feldspar + titanite, and (2) biotite + hornblende.

The leucocratic fresh Garam Chasma pluton consists of Afs $+\mathrm{Pl}+\mathrm{Ms}+\mathrm{Bt}$ and subordinate Grt + Sil bearing leucogranite (Fig. 3G and H) with accessory Tur + Zrn + Xtm + Urn + Mzn + Ap. Rare sericitization of alkali feldspar is observed. The leucocratic Garam Chasma pluton occurs as a single phase.

\section{WHOLE ROCK GEOCHEMISTRY}

Specimens from the Kafiristan, Tirich Mir, Buni-Zom, and Garam Chasma plutons were analysed for whole rock major and select trace element compositions through X-Ray fluorescence (XRF) on pressed pellet using a Bruker S8 TIGER instrument at the Saskatchewan Research Council (SRC) Geoanalytical Laboratories, Saskatoon, Canada. Additional trace and REE concentrations in select specimens were determined by lithium metaborate fusion - inductively coupled plasma mass spectrometry also at the SRC.

\subsection{Kafiristan Pluton}

Two specimens from the Kafiristan pluton (S60 and S81) were analyzed for major, trace and REE. Chemically, the specimens plot across the alkali granite and granitic fields of the Cox et al. (1979) classification diagram (Fig. 4). The two specimens have variable $\mathrm{SiO}_{2}$ (67.9-75.9 wt.\%), $\mathrm{Al}_{2} \mathrm{O}_{3}$ (13.1-14.4 wt.\%), $\mathrm{MgO}\left(0.16-0.9\right.$ wt \%), $\mathrm{P}_{2} \mathrm{O}_{5}(0.09-0.25$ wt\%), $\mathrm{CaO}(0.6-1.92 \mathrm{wt} \%)$ and $\mathrm{Fe}_{2} \mathrm{O}_{3}(1.29-4.76 \mathrm{wt} \%)$, and high $\mathrm{K}_{2} \mathrm{O}(4.48-5.70$ wt.\%) relative to $\mathrm{Na}_{2} \mathrm{O}(2.53-3.26$ wt.\%). Harker plots of major elements within the two analyzed specimens from the Kafiristan pluton show a significant difference in $\mathrm{K}_{2} \mathrm{O}, \mathrm{Na} 2 \mathrm{O}, \mathrm{CaO}, \mathrm{MgO} \mathrm{Al}_{2} \mathrm{O}_{3}$, $\mathrm{TiO}_{2}, \mathrm{Fe}_{2} \mathrm{O}_{3}$, and $\mathrm{P}_{2} \mathrm{O}_{5}$ contents between specimens when plotted against $\mathrm{SiO}_{2}$ (Fig. 5). 
Similarly, differences between specimens also exist in trace element concentration (e.g. $\mathrm{Rb}$, Sr, $\mathrm{Ba}, \mathrm{Zr}$ and $\mathrm{Th}$ ) vs. $\mathrm{SiO}_{2}$ plots (Fig. 5).

MORB-normalized spider plots of the Kafiristan pluton specimens show relative enrichment in Large Ion Lithophile Elements (LILE: e.g. Rb) compared to High Field Strength Elements (HFSE: e.g. $\mathrm{Nb}$ ), with pronounced negative anomalies in $\mathrm{Sr}$ and enrichments in Th (Fig. 6a). While on chondrite-normalized REE plots, S60 shows a moderate negative Eu anomaly and depleted heavy REE (Fig. 7a), whereas S81 has a 'V' shaped REE pattern and a pronounced negative Eu anomaly (Fig. 7a).

\subsection{Tirich Mir Pluton}

The five specimens of the Tirich Mir plutonic body (S24, S26, S28, S29 and S62) generally have restricted range in $\mathrm{SiO}_{2}(70.0-73.9 \%)$ and $\mathrm{Al}_{2} \mathrm{O}_{3}$ contents (14.4-16.2 wt\%), and wide ranges in $\mathrm{K}_{2} \mathrm{O}(2.17-6.22 \mathrm{wt} \%), \mathrm{Na}_{2} \mathrm{O}(2.18-4.83 \mathrm{wt} \%), \mathrm{P}_{2} \mathrm{O}_{5}(0.17-0.28 \mathrm{wt} \%)$, $\mathrm{MgO}(0.09-0.82 \mathrm{wt} \%)$ and $\mathrm{Fe}_{2} \mathrm{O}_{3}(0.59-2.32 \mathrm{wt} \%)$ (see Table 1). With the exception of S62, which has an affinity more toward alkali granite, the Tirich Mir specimens plot in the granite field of the Cox et al. (1979) $\mathrm{K}_{2} \mathrm{O}+\mathrm{Na}_{2} \mathrm{O}$ vs $\mathrm{SiO}_{2}$ classification diagram (Fig. 4). Major element Harker plots show generally negative slopes in $\mathrm{K}_{2} \mathrm{O}, \mathrm{MgO}, \mathrm{Fe}_{2} \mathrm{O}_{3}$ and $\mathrm{TiO}_{2}$ when plotted against $\mathrm{SiO}_{2} ; \mathrm{Na}_{2} \mathrm{O}$ has a positive slope (Fig. 5). Furthermore, trace element Harker

plots of $\mathrm{Ba}, \mathrm{Sr}$ and $\mathrm{Zr}$ show negative relationships with $\mathrm{SiO}_{2}$ while Th has a variable relationship (Fig. 5).

On MORB-normalized trace element diagrams, S24, S28, and S62 have similar LILE and HFSE values, with relative enrichment in $\mathrm{Rb}$, Th, and variably negative $\mathrm{Sr}$ and $\mathrm{Nb}$ anomalies (Fig. 6b). Chondrite-normalized spider plots of the Tirich Mir specimens show 
relative enrichment in light $\left.\mathrm{REE}\left((\mathrm{La} / \mathrm{Yb})_{\mathrm{N}}=8-14\right)\right)$, depletion in heavy REE and moderate negative Eu anomalies (Fig. 7b).

\subsection{Buni-Zom Pluton}

The three specimens analyzed (S47, S95 and S96) from the Buni-Zom pluton show a wide compositional range in $\mathrm{SiO}_{2}(57.1-71.8 \mathrm{wt} \%), \mathrm{MgO}(0.91-3.82 \mathrm{wt} \%), \mathrm{P}_{2} \mathrm{O}_{5}(0.2-0.43$ $w t \%), \mathrm{CaO}(2.1-7.12 \mathrm{wt} \%)$, and $\mathrm{F}_{2} \mathrm{O}_{3}(2.27-8.65 \mathrm{wt} \%) . \mathrm{Na}_{2} \mathrm{O}$ within a specimen is typically higher than $\mathrm{K}_{2} \mathrm{O}$. The Buni-Zom specimens variably plot within the diorite and granite fields of Cox et al. (1979) (Fig. 4). Major-element Harker diagrams show negative relationships for $\mathrm{CaO}, \mathrm{MnO}, \mathrm{P}_{2} \mathrm{O}_{5}, \mathrm{TiO}_{2}, \mathrm{MgO}, \mathrm{Fe}_{2} \mathrm{O}_{3}$ with increasing $\mathrm{SiO}_{2}$ (Fig. 5). In contrast, Sr shows a positive relationship with $\mathrm{SiO}_{2}$; a similar, though weaker, relationship may exist with $\mathrm{Ba}$ and $\mathrm{Rb}$ (Fig. 5).

MORB-normalized trace element plots for the Buni-Zom specimens show some variation in LILE and HFSE (Fig. 6c; Table 1). The specimens show generally similar distributions of LILE with a pronounced negative Sr anomaly, however, specimen S95 shows more enrichment in Th and less depletion in $\mathrm{Nb}$ compared to S47 and S96. The chondritenormalized REE pattern of the two specimens analysed have uniform negative slopes with minor positive Ho anomalies (Fig. 7c), however, specimen $\left.\mathrm{S} 96\left((\mathrm{La} / \mathrm{Yb})_{\mathrm{N}}=9\right)\right)$ is more enriched in heavy REE than S95 $\left.\left((\mathrm{La} / \mathrm{Yb})_{\mathrm{N}}=17\right)\right)$.

\subsection{Garam Chasma Pluton}

The four specimens analyzed from the Garam Chasma pluton have a narrow range of compositional variation in $\mathrm{SiO}_{2}(72.2-75.0 \mathrm{wt} \%), \mathrm{MgO}(0.11-0.24 \mathrm{wt} \%), \mathrm{P}_{2} \mathrm{O}_{5}(0.08-0.17$ 
wt $\%), \mathrm{CaO}(0.69-1.32 \mathrm{wt} \%), \mathrm{F}_{2} \mathrm{O}_{3}(0.63-1.41 \mathrm{wt} \%) ; \mathrm{K}_{2} \mathrm{O}(4.11-5.39 \mathrm{wt} \%)$ and $\mathrm{Na}_{2} \mathrm{O}(2.61-$ 3.79 wt\%). Compositionally, the Garam Chasma specimens plot in the alkali granite and granite fields of the Cox et al. (1979) discrimination diagram (Fig. 4). The only trends apparent on major element Harker plots are negative relationships between $\mathrm{Na}_{2} \mathrm{O}$ and $\mathrm{Al}_{2} \mathrm{O}_{3}$ against $\mathrm{SiO}_{2}$ (Fig. 5).

The MORB-normalized spidergram of specimens S9A, S9B, S10 and S10B from the Garam Chasma pluton show similar concentrations in LILE with strong negative $\mathrm{Sr}$ anomalies. Moreover, Th shows moderate enrichment in the specimens while Nb shows minor relative depletion (Fig. 6d). The two specimens, S9A and S10B, of the Garam Chasma pluton analyzed for REE concentrations show enrichment in light REE $\left.\left((\mathrm{La} / \mathrm{Yb})_{\mathrm{N}}=29-56\right)\right)$, with similar decreasing slopes towards heavy REE on chondrite-normalized plots (Fig. 7d).

\section{INTERPRETATIONS AND PETROGENESIS}

\subsection{Kafiristan Pluton}

Though only constrained by two specimens, apparent decreasing $\mathrm{K}_{2} \mathrm{O}, \mathrm{CaO}, \mathrm{MgO}$, $\mathrm{Al}_{2} \mathrm{O}_{3}, \mathrm{TiO}_{2}, \mathrm{Fe}_{2} \mathrm{O}_{3}$, and $\mathrm{P}_{2} \mathrm{O}_{5}$ with increasing $\mathrm{SiO}_{2}$ in the Kafiristan pluton (Fig. 5) are consistent with fractionating of hornblende, plagioclase, and potentially biotite (e.g. White and Chappell, 1983). In addition, decreasing $\mathrm{Sr}, \mathrm{Ba}$, and $\mathrm{Zr}$ and increasing $\mathrm{Rb}$ contents from S60 to S81 are also consistent with a fractionating plutonic body (Crawford and Searle, 1992; Chappell and White, 1992; King et al., 1997; Dostal and Chatterjee, 2000; Liu et al., 2012). Moreover, the overall negative anomalies of $\mathrm{Eu}, \mathrm{Sr}$, and $\mathrm{Nb}$ in spidergrams of the two specimens (Fig. 7) may indicate significant fractional crystallization of plagioclase and 
titanite/ilmenite minerals (Wu et al., 2003). Enrichment of the Kafiristan specimens in heavy REE relative to chondrite may be attributed to the dissolution of either garnet/monazite and or allanite thereby liberating these elements (Crawford and Searle, 1992; Zhang et al., 2014).

The Kafiristan pluton specimens have generally high $\mathrm{Na}_{2} \mathrm{O}+\mathrm{K}_{2} \mathrm{O}$, Fe/Mg ratios show pronounced negative $\mathrm{Sr}$ anomalies (Figs. 5, 6). These signatures, along with high $\mathrm{Rb}$ (Fig. 6) and high total REE (Table 1) with significant negative Eu anomalies (Fig. 7) are consistent with geochemical signatures of plutonic bodies that have evolved from the partial melting of lower crust from a basaltic source (White and Chappell, 1983; Whalen et al., 1987; Eby 1990; Whalen et al., 1997; Wu et al., 2002; Li et al., 2007; King et al., 1997; Yang et al., 2011). Furthermore, high LILE/HFSE, Y/Nb (2.13-2.70) and $\mathrm{Yb} / \mathrm{Ta}(1.37-1.96)$ ratios, and with strong fractionation of $\mathrm{Ba}, \mathrm{Sr}$ and $\mathrm{Eu}$ are also consistent with derivation from a basaltic source (Figs. 5 and 7; Table 1; Eby, 1990; Li et al., 2013). The two specimens of the Kafiristan pluton are, therefore, interpreted to have resulted from the variable fractionation of magma from basaltic source in an anorogenic, perhaps rift-type, environment.

\subsection{Tirich Mir Pluton}

Minor sericitization was observed in specimens S24 and S62 from the Tirich Mir pluton, and minor chloritization was also noted in specimen S24. In both specimens the alteration typically follows fractures in alkali feldspar. In specimens S28 and S29, fractures in plagioclase crystals variably contain secondary calcite and/or chlorite minerals. The affect of chloritization and sericitization appear to be minor, as these specimens do not show any significant alteration trend and generally plot within range of an average fresh granitic body (Fig. 8). All specimens are, therefore, considered for interpretation below. 
The general trends of decreasing $\mathrm{K}_{2} \mathrm{O}, \mathrm{Fe}_{2} \mathrm{O}_{3}, \mathrm{MgO}$, and $\mathrm{TiO}_{2}$ with increasing $\mathrm{SiO}_{2}$ in the Tirich Mir pluton is consistent with crystal fractionation of K-bearing Fe-Mg rich minerals (biotite or perhaps hornblende as reported by Searle et al., 2001), and plagioclase (White and Chappell, 1983; Li et al., 2007). Moreover, the negative $\mathrm{Ba}$ and $\mathrm{Sr}$ anomalies also indicate removal of a K-bearing phase by fractionation crystallization (Rex et al., 1988; Guillot and Le Fort, 1995; Liu et al., 2012). The negative Eu anomalies in the Tirich Mir specimens are consistent with plagioclase-controlled magmatic fractionation or occurrence in the residuum. The higher light REE relative to heavy REE in the Tirich Mir specimens may indicate accessory mineral, such as monazite/allanite, fractionation and retention of garnet in the residue (Rex et al., 1988).

Most of the Tirich Mir specimens generally have high $\mathrm{K}_{2} \mathrm{O}\left(\mathrm{Na}_{2} \mathrm{O} / \mathrm{K}_{2} \mathrm{O}<1\right)$, low heavy REE, are associated with a moderately negative $\mathrm{Eu}$ anomaly, and low $\mathrm{Sr} / \mathrm{Y}$ and $\mathrm{Nb} / \mathrm{Ta}$ ratios, all consistent with derivation from partial melting of mafic/ultramafic lower crustal and upper mantle (mantle wedge) material in a continental arc setting (White and Chappell, 1983; Li et al., 2007; Zhang et al., 2014). Moreover, the high LILE/HFSE ratios with notable negative $\mathrm{Nb}$ anomalies of the Tirich Mir specimens are characteristic of subduction-related melting (Li et al., 2007; Zhang et al., 2014). This interpretation is also supported by a pronounced negative $\mathrm{Sr}$ anomaly and more moderately negative $\mathrm{Ba}$ and $\mathrm{Eu}$ anomalies, indicative of fractionation of arc magmas (Li et al., 2007; Yang et al., 2010; Ji et al., 2009; Zhang et al., 2014). The Tirich Mir pluton is, therefore, interpreted to have evolved from a fractionated, subduction-related igneous magma source with variable contribution from sedimentary/crustal rocks through assimilation. 


\subsection{Buni-Zom Pluton}

Major element composition, hand specimen, and petrographic examination outline two distinct phases in the Buni-Zom pluton: 1) a low silica phase and 2) a high silica phase. The low silica phase specimen (S96) is dominated by Pl, Afs, Bt, Hbl, and Ttn, while the high silica phase specimen (S95) has a similar mineralogy but lacks hornblende. The relatively low ASI values 0.7-1.1 (Table 1), wide ranging compositions, and presence of $\mathrm{Hbl}$ and Ttn (accessory) are characteristic of a intrusive rocks generated from an igneous protolith (White and Chappell, 1983; Chappell and White, 2001). Major-element Harker diagrams show negative relationships between $\mathrm{CaO}, \mathrm{MnO}, \mathrm{P}_{2} \mathrm{O}_{5}, \mathrm{TiO}_{2}, \mathrm{MgO}$, and $\mathrm{Fe}_{2} \mathrm{O}_{3}$ with $\mathrm{SiO}_{2}$ while $\mathrm{K}_{2} \mathrm{O}$ shows the opposite, consistent with a fractionation of minerals such as hornblende, biotite, and plagioclase. Moreover, the amphibole free specimen (S95) has higher alkali, LILE and HFSE also consistent with a fractionating magmatic source (Whalen et al., 1987; Crawford and Windley, 1990; Chappell, 1999; Chu et al., 2009; Deng et al., 2011).

Chondrite-normalized REE patterns have fairly uniform negative slopes with the less evolved diorite, specimen S96, showing more enrichment in heavy REE $\left((\mathrm{La} / \mathrm{Yb})_{\mathrm{N}}=9\right)$ than the more evolved S95 $\left.\left((\mathrm{La} / \mathrm{Yb})_{\mathrm{N}}=17\right)\right)$, consistent with fractional crystallization of magma. The absence of a Eu anomaly and the high $\mathrm{Sr}(663-826 \mathrm{ppm})$ content of the Buni-Zom specimens are compatible with plagioclase incorporated into the melt or a plagioclase-free source. The depletion in $\mathrm{Nb}$ and $\mathrm{Ti}$ and very low $\mathrm{Nb} / \mathrm{Ta}$ ratios $(0.1-0.7)$ indicates that the 
protolith to the Buni-Zom pluton has amphibole, titanite and/or rutile in the residuum (Mahoney et al., 1998; Zhang et al., 2014).

\subsection{Garam Chasma Pluton}

Harker plots of the Garam Chasma pluton are typically scattered, however, $\mathrm{Na}_{2} \mathrm{O}$ has a negative relationship with $\mathrm{SiO}_{2}$, consistent with the fractionation of plagioclase. Such an interpretation is consistent with higher $\mathrm{K}_{2} \mathrm{O}(5.4-4.1 \mathrm{wt} \%)$ over $\mathrm{Na}_{2} \mathrm{O}(3.3-2.6 \mathrm{wt} \%)$, and high $\mathrm{Rb}$, as well as the presence of aluminous phases such as garnet and sillimanite in the Garam Chasma specimens (e.g. Chappell and White, 2001; Villaros, 2010).

The very high LILE/HFSE (high $\mathrm{Rb} / \mathrm{Nb}+\mathrm{Y}$ ratios) and LREE/HREE ratios in the specimens $(\mathrm{La} / \mathrm{Yb}=41.94-81.82)$, and a relatively pronounced negative $\mathrm{Nb}$ anomaly are consistent with a magma from a crustal source (Chappell, 1999; Chu et al., 2009; Deng et al., 2011). Relative depletion of heavy REE and the absence of a negative Eu anomaly indicates that REE-bearing phases such as garnet/monazite/allanite remained in the source while and plagioclase was either absent in the source or contributed to the melt. Trace element abundances of $\mathrm{Rb}, \mathrm{Ba}$ and $\mathrm{Sr}$ define an array of strongly increasing $\mathrm{Rb} / \mathrm{Sr}$ with decreasing $\mathrm{Ba}$ (Fig. 10) indicative of vapor-absent incongruent melting of muscovite (Harris and Inger, 1992; Inger and Harris, 1993). Similar vapor-absent melting of a muscovite-bearing protolith has been found to be associated with decompressional melting along the Himalayan orogen (Langtang, Fig. 10; Harris and Massey, 1994; Prince et al., 2001; Searle et al., 1999; King et al., 2011; King and Harris, 2013). The geochemical and geochronological (discussed below) similarities of the Garam Chasma specimens to the Baltoro (Karakoram; Searle et al., 1989), Bhagirathi lecucogranite (Garhwal, India; Stern et al., 1989), and Manaslu (Nepal; Guillot 
and Le Fort, 1995) plutons of the Himalaya, and North Himalayan decompression-related plutons: Gomdre, Kouwu and Majia (King et al., 2011) and Leo Pargil dome (NW India; Lederer et al., 2013), indicate that the Garam Chasma leucogranite may have evolved through a similar processes of crustal anatexis during collisional orogenesis.

\section{GEOCHRONOLOGY}

Considerable variation is observed in published data, with a wide range of variably concordant dates for specimens from the Tirich Mir, Buni-Zom and Garam Chasma plutonic bodies. Published ages are typically interpreted based on only a few concordant analyses or extrapolated from arrays of data variably affected by $\mathrm{Pb}$ loss (Hildebrand et al., 1998; Hildebrand et al., 2000; Heuberger et al., 2007); moreover, there is no previous record of U$\mathrm{Pb}$ geochronology from the Kafiristan pluton. New $\mathrm{U}-(\mathrm{Th}) / \mathrm{Pb}$ geochronology data were acquired using laser ablation paired with a multicollector inductively coupled plasma-mass spectrometer (LA-MC-ICP-MS) at the University of Santa Barbara, California (for detailed methodology see Cottle et al., 2011; 2013). This approach to dating specimens collected from the Hindu Kush allows specific domains of zircon and/or monazite, imaged through cathodoluminescence (CL) and/or electron backscatter imaging, to be targeted avoiding potential problems associated with mixing of distinct age domains.

Isoplot v2.4 (Ludwig 2000) was used to calculate both Tera-Wasserburg concordia diagrams (Fig. 11) for Kafiristan, Tirich Mir, Buni-Zom and Garam Chama pluton using the ${ }^{238} \mathrm{U},{ }^{235} \mathrm{U}$ and ${ }^{232} \mathrm{Th}$ decay constants of Steiger and Jäger (1977).

\subsection{Kafiristan Pluton}


The LA-MC-ICP-MS results for two specimens, S80 and S60, from the Kafiristan pluton are reported along with isotopic ratios and calculated ages in Table 2. Zircon grains from the two specimens of the Kafiristan pluton are euhedral and typically show oscillatory zonation under CL consistent with the zircon grains being magmatic (Corfu et al., 2003; Fig. 11) The rims of the grains were the primary targets during analysis to avoid any potential inherited domains. Forty analyses were obtained while targeting the outer rims of thirtyseven zircon grains from S80. Two anomalously young zircon ages (S80_04 and S80_31) and a single spot missing the target (S80_35) were excluded from interpretation (Table 2). Tera-Wasserburg concordia (uncorrected for common $\mathrm{Pb}$ ) exhibit a broad dispersion between 495-525 Ma (Fig. 11). While most of the data are concordant, some show a slight discordance consistent with a minor common $\mathrm{Pb}$ component (Fig. 11). The youngest concordant age from S80 is $492 \pm 3.2 \mathrm{Ma}$, which is taken as the minimum crystallization age of this specimen.

Thirty analyses were obtained from an equal number of zircon grains separated from S60. The dates from this specimen are generally concordant and spread between $\sim 487 \mathrm{Ma}$ and $525 \mathrm{Ma}$ (Fig. 11), with a minimum crystallization age of $486.7 \pm 5.4 \mathrm{Ma}$. Some of the analyses are slightly discordant suggestive of minor common $\mathrm{Pb}$ or minor $\mathrm{Pb}$ loss (Fig. 11).

The two analyzed specimens of the Kafiristan pluton outline a protracted magmatic history spanning between ca. 488-525 Ma. Dates from both specimens (representing geochemical distinct phases in the Kafiristan pluton as observed above) overlap and are, therefore, interpreted to indicate that the two phases are the result of a single protracted magmatic event. The new dates obtained are within uncertainty of a previous whole rock $\mathrm{Rb} / \mathrm{Sr}$ crystallization age of $483 \pm 21 \mathrm{Ma}$ (Debon et al., 1987). 


\subsection{Tirich Mir Pluton}

$\mathrm{U}-\mathrm{Pb}$ (zircon) dating was carried out specimen on S24 of the Tirich Mir specimen. CL images of euhedral zircon from the Tirich Mir specimen display undisturbed oscillatory patterns indicating that the zircon grains are magmatic (Fig. 11). Fifteen analyses were obtained from eight zircon grains (Table 2). Two of the analyses (S24_007 and S24_012) were excluded as they yield anomalously older ages (early Paleozoic and Mesoproterozoic, respectively) than most of the specimen (Early Cretaceous). The two old analyses may reflect detrital/inherited zircon components. The remaining analyses from specimen S24 spread between ca. 123 and 127 Ma (Fig. 11). Most of the data acquired are concordant but three spots suggest the presence of some common $\mathrm{Pb}$ (Fig. 11).

The spread in dates from the Tirich pluton specimen is interpreted to indicate continuous crystallization from ca. 123-127 Ma with a final crystallization age of $123.7 \pm 0.7$ Ma. This minimum age is similar to, but somewhat older than, the previously published date of Heuberger et al. (2007), $121 \pm 1 \mathrm{Ma}$, and significantly older than the $114 \pm 2 \mathrm{Ma}$ date of Hildebrand et al., (2001), indicating that crystallization/magmatism within the pluton may have a protracted history.

\subsection{Buni-Zom Pluton}

The U-Pb analytical results on two specimens, S92 (intermediate phase) and S95 (high $\mathrm{SiO}_{2}$ phase) of the Buni-Zom body are given in Table 2. Zircon from both specimens are typically elongate and euhedral with oscillatory zoning, consistent with a magmatic origin (Fig. 11). A total of Forty analyses were obtained from the rims of thirty-four grains 
from S92. Three of the analyses (S92_004, S92_023 and S92_033) yielded anomalous ages and were excluded from further interpretation. Two of the excluded zircon ages, $119 \pm 0.8$ $\mathrm{Ma}$ (S92_004) and 115.8 $\pm 1 \mathrm{Ma}$ (S92_023), may be associated with earlier magmatism in an Andean-type setting along the southern margin of Eurasia (discussed below), while $727 \pm 6$ Ma (S92_033) is considered an inherited age. The remaining concordant dates spread between $\sim 102$ and $110 \mathrm{Ma}$ (Fig. 11), with a minimum age of $101.8 \pm 0.6 \mathrm{Ma}$. Similarly, Forty spot ages were obtained from targeting the rims of thirty-six zircon grains from specimen S95 (Table 2). The data acquired from these analyses yield dates that spread between $\sim 105$ and $109 \mathrm{Ma}$ (Fig. 11), yielding a minimum date of $104.7 \pm 0.7 \mathrm{Ma}$.

The ages from the two specimens of the Buni-Zom representing geochemically distinct phases overlap entirely and are interpreted to have evolved in a nearly continuous magmatic spanning for ca. 8 Ma years. The previously reported $103.8 \pm 0.27 \mathrm{Ma}$ crystallization age from the Buni-Zom (Heuberger et al., 2007) is in general agreement with the range of new data presented herein.

\subsection{Garam Chasma Pluton}

Monazite U-Th- $\mathrm{Pb}$ dating of the Garam Chasma leucogranite was performed on specimen $\mathrm{C} 65$ (Table 3). Because ${ }^{207} \mathrm{~Pb} /{ }^{235} \mathrm{U}$ dates are relatively imprecise in young monazite, ${ }^{208} \mathrm{~Pb} /{ }^{232} \mathrm{Th}$ dates are reported (Fig. 11). Most of the monazite dates are concordant, however, some reverse discordance is apparent in the ${ }^{208} \mathrm{~Pb} /{ }^{232} \mathrm{Th}$ vs. ${ }^{206} \mathrm{~Pb} /{ }^{238} \mathrm{U}$ plot indicating unsupported ${ }^{206} \mathrm{~Pb}$ from the decay of ${ }^{230} \mathrm{Th}$ (Schärer, 1984). Specimen C65 of the Garam Chasma pluton yields two apparent age populations: the older age population yields a weighted mean age $\left({ }^{208} \mathrm{~Pb} /{ }^{232} \mathrm{Th}\right.$ ) of $27.1 \pm 0.3$ (MSWD 0.6) and younger age population with 
a weighted mean ${ }^{208} \mathrm{~Pb} /{ }^{232} \mathrm{Th}$ date of $23.6 \pm 0.1 \mathrm{Ma}$ (MSWD 0.8). These two populations may indicate an episodic emplacement history. The dominant phase outlined in this study is consistent with the age of ca. 24 Ma interpreted by Hildebrand et al (1998) from discordant monazite and uraninite dates.

\section{DISCUSSION AND TECTONIC SIGNIFICANCE}

Recent metamorphic monazite ages from the Hindu Kush range (Faisal et al., 2014), along with sedimentary records from the nearby Pamir (Angiolini et al., 2013) outline a protracted tectonic history for the southern Eurasian margin in the region involving terrane accretion, plutonism, and related mountain building processes from the Mesozoic to the Cenozoic. The present study builds on this earlier work and outlines four distinct magmatic events in the Hindu Kush area spanning the Cambrian-Early Ordovician to the late Oligocene with affinities to a) intraplate extension/rifting, b) subduction-derived melts into a continental arc and c) synorogenic crustal anatexis. These magmatic episodes outline the regional magmatic and metamorphic history of the Hindu Kush and aid in a broader understanding of Himalaya geology and the tectonic evolution of the southern margin of Eurasia.

Geochemically, the Kafiristan pluton is ferroan, calc-alkalic to alkali-calcic, and weakly peraluminous to peraluminous consistent with generation in anorogenic extensional tectonic environment (Fig. 12a). The crystallization ages from the two specimens examined are indistinguishable, which indicates that the two phases of the pluton were part of the same magmatic event between 538 and 487 Ma. Such an event may reflect post-collisional rifting of the Gondwana supercontinent during the Paleozoic (e.g. Dèzes, 1999; Fernández et al., 
2012) with the Kafiristan pluton intruded as the Cimmerian terranes, including the Hindu Kush and Karakoram, rifted and drifted away from peri-Gondwana toward Eurasia (Sengör, 1979; Rogers et al., 1995; Gaetani, 1997; Heuberger, 2004; Zanchi and Gaetani, 2011). Similar Cambro-Orovician plutons interpreted to be related to the same rifting event have been identified in the nearby Zanskar (Dèzes, 1999), Karakoram (Le Fort et al., 1986; Noble and Searle, 1995; Rolland et al., 2002; Zanchi and Gaetani, 2011) and Wakhan (Debon et al., 1987) regions.

The continued subduction of Paleotethys oceanic lithosphere beneath the Hindu Kush-Karakoram led to the intrusion of the Tirich Mir and Bun-Zom plutons in the Cretaceous (Fig. 12d). U-Pb zircon geochronology from the Tirich Mir pluton outlines a magmatic event spanning 123 to $127 \mathrm{Ma}$, coeval with subduction-related magmatic activity and the intrusion of the Karakoram batholith farther east (Searle et al., 1989; Hildebrand et al., 2001; Heuberger et al., 2007 and references therein).

While like the Tirich Mir specimens, the Buni-Zom rocks show geochemical signatures of a plutonic body generated above a subduction zone, the absence of trends in $\mathrm{Al}_{2} \mathrm{O}_{3}, \mathrm{Na}_{2} \mathrm{O}, \mathrm{P}_{2} \mathrm{O}_{5}, \mathrm{CaO}$ and $\mathrm{MgO}$ in Buni-Zom specimens when plotted against $\mathrm{SiO}_{2}$ (Fig. 4), indicate that its source is less evolved. Moreover, high molecular Mg content as well as a close association with the calcic to calc-akalic boundary on the MALI (Figs. 9a and b) compared to the calc-alkalic to alkali-calcic nature of Tirich Mir specimens indicates that the Buni-Zom plutonic body was located farther toward the oceanic portions of the Andean -Arc related belt. This is consistent with their relative proximity to the paleo-Eurasian margin (to the SE of the field area) in the Cretaceous. 
The protracted Andean-style magmatism in the Hindu Kush recorded during the Early Cretaceous intrusion of the Tirich Mir and Buni-Zom plutons ceased as the Kohistan Island arc docked along the southern margin of Eurasia during the Late Cretaceous (Petterson et al., 1991; Fraser et al., 2001; Faisal et al., 2014; Fig. 12e). The continued subduction of the Neotethys along the accreted Kohistan arc to Eurasia culminated with the collision of India and Eurasia in the Eocene (Patriat and Achache, 1984; Beck et al., 1995; Fig. 12). The crustal shortening and thickening of the Indian and Eurasian margins during collision led to widespread anatexis and the intrusion of the Garam Chasma pluton in the Hindu Kush region during the Oligocene/Miocene (Fig. 12f). The general similarity in the geochemistry and age of the Garam Chasma pluton with other Cenozoic leucogranites from the Himalaya, e.g. Langtang (Inger and Harris, 1993), Manaslu (Guillot and Le Fort, 1995), North Himalaya lecucogranite (Gomdre, Kouwu and Majia, King et al., 2011) is consistent with regional scale anatexis across the Himalaya, Karakoram and Hindu Kush. The monazite dates from the Garam Chasm pluton are also consistent with published metamorphic monazite dates from the same area (Faisal et al., 2014) indicating that anatexis and metamorphism occurred synchronously in the Hindu Kush terrane during the Late Oligocene/Early Miocene.

\section{CONCLUSIONS}

The geochemical and geochronological data from the plutonic bodies of the Hindu Kush outline a protracted tectonomagmatic history of the southern margin of Eurasia that spans from the early Paleozoic into the Cenozoic. These data provide constraints on crustal 
growth and paragenesis along the southern margin of Eurasia prior to Cenozoic initiation of continental collision with India.

1. The Kafiristan pluton is a Cambro-Ordovician body interpreted to be associated with the break-up of Gondwana.

2. Subduction of the Paleotethys beneath the southern Eurasian margin after the accretion of the Hindu Kush and Karakoram terranes developed an Andean-style margin resulting in the Cretaceous emplacement of the Tirich Mir and Buni-Zom plutons.

3. The origin of the Cenozoic Garam Chasma pluton is attributed to crustal anatexis associated with the India-Eurasia collision. The crystallization age of the Garam Chasma leucogranite is coeval with sillimanite-grade metamorphism and intrusion of leucogranite bodies within the nearby Karakoram, Himalaya and regions.

\section{ACKNOWLEDGEMENTS}

The present research is a part of the Ph.D work of S. Faisal supported by NSERC Discovery grant to K. Larson. Faisal acknowledges logistic support from the National Centre of Excellence in Geology, University of Peshawar, Pakistan. Additional support was provided by the National Science Foundation under grant EAR-1119380 awarded to J. Cottle. Constructive feedback on by Asghar Ali

Figure 1. Tectonic map of Northern Pakistan and surrounding regions. MFT, Main Frontal Thrust; MBT, Main Boundary Thrust; MMT, Main Mantle Thrust; SS, Shyok Suture; TMF, Tirich Mir Fault Zone; EHK, East Hindu Kush; ACM, Alitchur mountains; RPZ, Rushan-Pshart Zone; WAS, Wanch-Ak Baital Suture; N-P, North Pamir; C-P, Central Pamir; SE-P, SE-Pamir; SW-P, SW-Pamir; WAZ, Waziristan; K, Kabul. 1, Quaternary; 2, Tertiary foredeeps; 3, Palaeozoic belts; 4, 
Terranes of Gondwanan affinity; 5, Kabul Block; 6, Wasser-Panjao Suture; 7, Waziristan ophiolitic complex; 8, Kohistan- Ladakh arc terranes; 9, Himalaya. Heavy lines represent main sutures (Redrawn after Gaetani et al., 1996; Zanchi et al., 2000). Insert rectangle shows the location of Figure 2.

Figure 2. Geology map of the Chitral region showing Kafiristan, Tirich Mir, Bun-Zom and Garam Chasma with specimen locations used for geochemical and geochronogical analyses noted.

Figure 3. Cross-polarized photomicrographs of the Kafiristan (A, B), Tirich Mir (C, D), Buni-Zom (E, F) and Garam Chasm (G, H). Mineral abbreviations after Whitney and Evans (2010).

Figure 4. The classification of the Kafiristan, Tirich Mir, Buni-Zom and Garam Chasma plutons in the $\mathrm{SiO}_{2}$ vs. $\mathrm{Na}_{2} \mathrm{O}+\mathrm{K}_{2} \mathrm{O}$ diagram (after Cox et al., 1979).

Figure 5. Chemical variation Harker diagrams of the Kafiristan, Tirich Mir, Buni-Zom and Garam Chasma plutons.

Figure 6. MORB-normalized trace plots of the Kafiristan (a), Tirich Mir (b), Buni-Zom (c) and Garam Chasma (d) specimens (after Sun and McDonough, et al., 1989).

Figure 7. Chondrite normalized REE diagrams of the Kafiristan (a), Tirich Mir (b), BuniZom (c) and Garam Chasma (d) specimens. Normalizing values are from McDonough and Sun (1995).

Figure 8. Ternary plot of $\mathrm{Al}_{2} \mathrm{O}_{3}-\left(\mathrm{CaO}+\mathrm{Na}_{2} \mathrm{O}\right)-\mathrm{K}_{2} \mathrm{O}$, showing common alteration trend of an average granitic composition. Data from the Hindu Kush plutons (Kafiristan, Tirich Mir, Buni-Zom and Garam Chasma) bodies generally cluster together (weathering trend and weathering data after Nesbitt and Young $(1984 ; 1989)$. See text for discussion.

Figure 9. a) $\mathrm{FeO}_{\text {tot }}\left(\mathrm{FeO}_{\text {tot }}+\mathrm{MgO}\right)$ versus weight per cent $\mathrm{SiO}_{2}$ diagram showing the boundary between ferron (Kafiristan and Garams Chasma) and magnesian (Tirich Mir and Buni-Zom) plutons (after Frost et al., 2001). b) $\mathrm{NaO}+\mathrm{K}_{2} \mathrm{O}-\mathrm{CaO}$ versus weight per cent $\mathrm{SiO}_{2}$ plot showing the compositional range of Kafiristan, Tirich Mir, Buni-Zom and Garam Chasma plutons (after Frost et al., 2001).

Figure 10. $\mathrm{Rb} / \mathrm{Sr}$ versus $\mathrm{Sr}$ and Ba diagram (after Inger and Harris, 1993) for Garam Chasma and Langtang (from Inger and Harris, 1993) leucogranites. Mu (VA)-vapourabsent muscovite melting; $\mathrm{Bi}$ (VA)-vapour-absent biotite melting. $\mathrm{F}=$ melt fraction. 
Figure 11. Tera-Wasserburg concordia diagrams showing analytical data for zircons from Kafiristan, Tirich Mir and Buni-Zom plutons. Concordia diagram for Garam Chasma pluton specimen with ${ }^{208} \mathrm{~Pb} /{ }^{232} \mathrm{Th}$ ratios along the $\mathrm{x}$-axis. Note, the Garam Chasma data are shown as crosses because errors are not correlated. See text for details. Cathodoluminescence images of representative zircons from Kafiristan, Tirich Mir and Buni-Zom are shown with the relevant concordia plots along with a backscattered monazite image from the Garam Chasma pluton.

Figure 12. Schematic cross-sectional evolutionary model of the southern Eurasian margin. See text for discussion (modified after Hildebrand et al., 2001; Burg 2011; Zanchi and Gaetani 2011; Angiolini et al., 2013, Faisal et al., 2014). CP = Central Pamir, $\mathrm{SP}-\mathrm{HK}=$ South Pamir - Hindu Kush, KK $=$ Karakoram, NG $=$ Northern Gondwana, KIA = Kohistan Island Arc, RPB = Rushan-Pshart Basin, RPS = Rushan-Pshart Suture, TWB = Tirich-Wakhan Basin, TMBZ = Tirich Mir Boundary Zone, PT = Paleotethys, NT = Neotethys, MKT (Northern Suture) $=$ Main Karakoram Thrust, ISZ = Indus Suture Zone.

Table 1. Major elements (\%), trace elements and rare-earth elements (ppm) of the plutonic bodies in the Eastern Hindu Kush, from the Chitral area, NW Pakistan.

Table. 2. LA-ICP-MS U-Pb geochronology data for spot analysis of zircon of the Kafiristan, Tirich Mir and Buni-Zom plutons.

Table 3. LA-ICP-MS U-Th/Pb geochronology data for spot analysis of monazite of the Garam Chasm pluton.

\section{REFERENCES:}

Angiolini, L., Zanchi, A., Zanchetta, S., Nicora, A., Vezzoli, G., 2013. The Cimmerian geopuzzle: new data from South Pamir. Terra Nova 25, 352-360.

Aslam, M., Khan, A., Ashraf, M., 2007. Geology and mineral resources of Chitral District, NWFP, Pakistan. Records of The Geological Survey of Pakistan 126, 1-30.

Bagas, L., Bierlein, F.P., Anderson, J.A.C., Mass, R., 2010. Collision-related granitic magmatism in the Granites-Tanami Orogen, Western Australia. Precambrian Research $177,212-226$.

Beck, R.A., Burbank, D.W., Sercombe, W.J., Riley, G.W., 229 Barndt, J.K., Berry, J.R., Afzal, J., Khan, A.M., Jurgen, H., Metje, J., Cheema, A., Shafique, N.A., Lawreence, R.D., Khan, A., 1995. Stratigraphic evidence for an early collision between northwest India and Asia. Nature 373, 55-58. 
Buchroithner, M.F., Gamerith, H., 1986. On the geology of the Tirich Mir area, central Hindu Kush (Pakistan). Jahrbuch Geologische Bundesanst 128, 367-381.

Burg, J. P., 2011. The Asia-Kohistan-India collision: Review and Discussion. In: Brown, D., Ryan, P.D. (eds) Arc-Continent Collision, Frontiers in Earth Sciences, Springer, pp. 279-309.

Calkins, J.A., Jamiluddin, S., Bhuyan, K., Hussain, A., 1981. Geology and Mineral Resources of the Chitral-Parstan Area, Hindu Kush Range, Northern Pakistan. Geological Survey (USA) Professional Paper 716-G.

Chappell, B.W., 1999. Aluminium saturation in I- and S-type granites and the characterization of fractionated haplogrnites. Lithos 46, 535-551.

Chappell, B.W., White, J.R., 1974. Two contrasting granite types. Pacific Geology 8, 173174.

Chappell, B.W., White, J.R., 2001. Two contrasting granite type: 25 years later. Australian Journal of Earth Sciences 48, 489-499.

Chu, M.F., Wang, K.L., Griffin, W.L., Chung, S.L., O'Reilly, S.Y., Pearson, N.J., Iizuka, Y., 2009. Apatite composition: Tracing petrogenetic processes in Transhimalayan granitoids. Journal of Petrology 50(10), 1829-1855.

Corfu, F., Hanchar, J.M., Hoskin, P.W.O., Kinny, P., 2003. Atlas of zircon textures. In: Hanchar, J., Hoskin, P.W.O. (Eds.), Zircon. Reviews in Mineralogy and Geochemistry 53. Mineralogical Society of America, pp. 469-500.

Cottle, J.M., Waters, D.J., Riley, D., Beyssac, O., Jessup, M.J., 2011. Metamorphic history of the South Tibetan detachment system, Mt. Everest region, revealed by RSCM thermometry and phase equilibria modeling. Journal of Metamorphic Geology 29, p. $561-582$.

Cottle, J.M., Burrows, A.J., Kylander-Clark, A., Freedman, P.A., Cohen, R.S., 2013. Enhanced sensitivity in laser ablation multi-collector inductively coupled plasma mass spectrometry. J. Anal. Atom. Spectrom., 28, 1700-1706.

Cox, K.G., Bell, J.D., Pankhurst, R.J., 1979. The interpretation of igneous rocks: London, Allen and Unwin, 450pages.

Crawford, M.B., Windley, B.F., 1990. Leucogranites of the Himalaya/Karakoram: implications for magmatic evolution within collisional belts and the study of collisionrelated leucogranite petrogenesis. Journal of Volcanology and Geothermal Research $44,1-19$. 
Crawford, M.B., Searle, M.P., 1992. Field relationships and geochemistry of pre-collisional (India-Asia) granitoid magmatism in the central Karakoram, northern Pakistan. Tectonophysics 206, 171-192.

Debon, F., Afzali, H., LeFort, P., Sonet, J., 1987. Major intrusive stages in Afghanistan: typology, age, and geodynamic setting. Geologische Rundschau 76(1), 245-264.

Deng, J., Yang, X., Sun, W., Huang, Y., Chi, Y., Yu, L., Zhang, Q., 2011. Petrology, geochemistry, and tectonic significance of Mesozoic shoshonitic volcanic rocks, Luzong, volcanic basin, eastern China. International Geology Review 54(6), 714-736.

Desio, A., 1964. On the geological age of some granites of the Karkaoram, Hindu Kush and Badakhshan (central Asia). In: Proceeding of the $22^{\text {nd }}$ International Geological Congress, Delhi, Part II, Section 11, 479-496.

Dèzes, P., 1999. Tectonic and Metamorphic Evolution of the Central Himalayan Domain in Southeast Zanskar (Kashmir, India). Mémoires de Géologie (Lausanne) 32, 160 pages.

Dostal, J., Chatterjee, A.K., 2000. Contrasting behaviour of $\mathrm{Nb} / \mathrm{Ta}$ and $\mathrm{Zr} / \mathrm{Hf}$ ratios in a peraluminous granitic pluton (Nova Scotia, Canada). Chemical Geology 163, 207-218.

Eby, G.N., 1990. The A-type granitoids: A review of their occurrence and chemical characteristics and speculations on their petrogenesis. Lithos 26, 115-134.

Eby, G.N., 1992. Chemical subdivision of the A-type granitoids: Petrogenetic and tectonic implications. Geology 20, 641-644.

Faisal, S., Larson, K.P., Cottle, J.M., Lamming, J., 2014. Building the Hindu Kush: Monazite records of terrane accretion, plutonism, and evolution of the Himalaya-KarakoramTibet Orogen. Terra Nova 26 (5), 396-401.

Faryad, S.W., Collett, S., Petterson, M., Sergeev, S.A., 2013. Magmatism and metamorphism linked to the accretion of continental blocks south of the Hindu Kush, Afghanistan. Lithos 175-176, 302-314.

Fraser, J.E., Searle, M.P., Parrish, R.R., Noble, S.R., 2001. Chronology of deformation, metamorphism and magmatism in the southern Karakoram Mountains. Geological Society of America Bulletin 113, 1443-1455.

Fernández, R.D., Castiñeiras, P., Barreiro, J.G., 2012. Age constraints on Lower Paleozoic convection system: Magmatic events in the NW Iberian Gondwana Margin. Gondwana Research 21, 1066-1079.

Frost, B.R., Barnes, C.G., Collins, W.J., Arculus, R.J., Ellis, D.J., Frost, C.D., 2001. A geochemical classification for granitic rocks. Journal of Petrology 42(11), 2033-2048. 
Frost, C.D., Frost, B.R., 1997. Reduced rapakivi-type granites: The tholeitte connection. Geology 25(7), 647-650.

Guillot, S., Le Fort, P., 1995. Geochemical constraints on the bimodal origin of High Himalayan leucogranite. Lithos 35, 221-234.

Gaetani, M., 1997. The Karakorum Block in Central Asia, from Ordovician to Cretaceous. Sedimentary Geology 109, 339-359.

Green, O.R., Searle, M.P., Corfield, R.I., and Corfield, R.M., 2008. Cretaceous-Tertiary carbonate Platform Evolution and the age of the India-Asia collision along the Ladakh Himalaya (Northwest India). Journal of Geology 116, 331-353.

Harris, N., Inger, S., 1992. Trace element modeling of pelite-derived granites. Contributions to Mineralogy and Petrology 110, 46-56.

Harris, N., Massey, J., 1994. Decompression and anatexis of Himalayan metapelites. Tectonics 13, 1537-1546.

Hawkesworth, C.J., Gallagher, K., Hergt, J.M., McDermont, F., 1993. Mantle and slab contribution in arc magmas. Annual Review of Earth and Planetary Sciences 21, 175204.

Heuberger, S., 2004. Kinematics of the Karakoram-Kohistan suture zone, Chitra, NW Pakistan. Unpublished Ph.D Thesis, Swiss Federal Institute of Technology Zurich, 189 p.

Heuberger, S., Schaltegger, U., Burgi, J.P., RG1, Villa, I.M., Frank, M., Dawood, H., Hussain, S., Zanchi, A., 2007. Age and isotopic constraints on magmatism along the Karakoram-Kohistan Suture Zone, NW Pakistan: evidence for subduction and continued convergence after India-Asia collision. Swiss Journal of Geosciences 100, $85-107$.

Hildebrand, P.R., 1998. The Hindu Kush of Pakistan: mountain range evolution from active to continental-continental collision. Ph.D thesis, University of Oxford, 118p.

Hildebrand, P.R., Noble, S.R., Searle, M.P., Parrish, R.R., Shakirullah, 1998. Tectonic significance of $24 \mathrm{Ma}$ crustal melting in the eastern Hindu Kush, Pakistan. Geology 26(10), 871-874.

Hildebrand, P.R., Searle, M.P., Shakirullah, Khan, Z., Van Heijst, H.J., 2000. Geological evolution of the Hindu Kush, NW Frontier Pakistan: active margin to continentcontinent collision zone. In: Khan, M.A., Treloar, P.J., Searle, M.P., \& Jan, M.Q. (eds) Tectonics of the Nanga Parbat Syntaxis and the Western Himalaya. Geological Society, London, Special Publication 170, pp. 277-293. 
Hildebrand, P.R., Noble, S.R., Searle, M.P., Waters, D.J., Parrish, R.R., 2001. Old origin for an active mountain range: Geology and geochronology of eastern Hindu Kush, Pakistan. Geological Society of America Bulletin 113(5), 625-639.

Inger, S., Harris, N., 1993. Geochemical constraints on Leucograntie magmatism in the Langtang Valley, Nepal Himalayas. Journal of Petrology 34, 345-368.

Ji, W.Q., WU, F.Y., Liu, C.Z., 2009. Geochronology and petrogenesis of granitic rocks in Gangdese batholith, southern Tibet. Science in China Series D: Earth Sciences 52(9), $1240-1261$.

Ludwig, K.R., 2000. User's manual for Isoplot/Ex version 2.4: a geochronological toolkit for Microsoft Excel. Berkeley Geochronological Center, Special Publication No. 1a

King, P.L., White, A.J.R., Chappell, B.W., Allen, C.M., 1997. Characterization and origin of aluminous A-type granites from the Lachlan Fold Belt, southeastern Australia. Journal of Petrology 38, 371-391.

King, J.A., Harris, N., Argles, T., and Parrish, R.R., 2011. The contribution of crustal anatexis to the tectonic evolution of Indian crust beneath Southern Tibet: Geological Society of America Bulletin 123 (1-2), 218-239.

King, J.A., Harris, N., 2013. What is the Significance of Oligocene melting in the Himalaya? $28^{\text {th }}$ Himalayan-Karakoram-Tibet Workshop Abstract Volume, Tubingen University, Germany: 22nd-24th August 2013.

Lederer, G.W., Cottle, J.M., Jessup, M.J., Langille, J.M., Ahmad, T., 2013. Timescales of partial melting in the Himalayan middle crust: insight from the Leo Pargil dome, northwest India. Contribution to Mineralogy and Petrology 166, 1415-1441.

LeFort, P., Debon, F., Pêcher, A., Sonet, J., Vidal, P., 1986. The 500 Ma magmatic event in alpine southern Asia, a thermal episode at Gondwana scale: Sciences de la Terre, Memoir 47, 191-209.

Li, S., Wang, T., Wilde, S. A., Tong, Y., 2013. Evolution, source and tectonic significance of Early Mesozoic granitoid magmatism in the Central Asian Orogenic belt (Central segment). Earth-Science Reviews 126, 206-234.

Li, X.H., Li, Z.X., Li, W.X., Liu, Y., Yuan, C., Wei, G., Qi, C., 2007. U-Pb zircon, geochemical and $\mathrm{Sr}-\mathrm{Nd}-\mathrm{Hf}$ isotopic constraints on age and origin of Jurassic I- and Atype granites from central Guangdong, SE China: A major igneous event in response to foundering of a subducted flat-slab? Lithos 96, 186-204.

Liu, S., Hu, R., Gao, S., Feng, C., Coulson, I.M., Feng, G., Qi, Y., Yang, Y., Yang, C., Tang, L., 2012. U-Pb zircon age, geochemical and $\mathrm{Sr}-\mathrm{Nd}$ isotopic data as constraints on the 
petrogenesis and emplacement time of andesites from Gerze, southern Qiangtang Block, northern Tibet. Journal of Asian Earth Sciences 45, 150-161.

Martin, H., 1999. The mechanisms of petrogenesis of the Archaean continental crust Comparison with modern processes, Lithos 30, 373-388.

Mahoney, J.J., Frei, R., Tejada, M.L.G, Mo, X.X., Leat, P.T., 1988. Tracing the Indian ocean mantle domain through time: isotopic results from old west Indian, east Tethyan and south Pacific seafloor. Journal of Petrology 39, 1285-1306.

McDonough, W.F. and Sun, S., 1995. The composition of the earth. Chemical Geology 120, $223-253$

Nesbitt H. W., Young G. M., 1984. Prediction of some weathering trends of plutonic and volcanic rocks based on thermodynamic and kinetic considerations. Geochim. Cosmochim. Acta 48, 1523-1534.

Nesbitt H. W., Young G. M., 1989. Formation and diagenesis of weathering profiles. J. Geol. 97, 129-147.

Noble, S.R., Searle, M.P., 1995. Age of crustal melting and leucogranite formation from UPB zircon and monazite dating in the western Himalaya, Zanskar, India. Geology 23(12), 1135-1138.

Parrish, R.R., Tirrul, R., 1989. U-Pb age of the Baltoro granite, northwest Himalaya, and implication for monazite U-Pb systematics. Geology 17, 1076-1079.

Patriat, P., Achache, J., 1984. India-Eurasia collision chronology has implications for crustal shortening and driving mechanism of plates. Nature 311, 615-621.

Pearce, J.A., Harris, N.B.W., Tindle, A.G., 1984. Trace element discrimination diagrams for the tectonic interpretation of granitic rocks. Journal of Petrology 25, 956-983.

Petterson, M.G., Windley, B.F., 1991. Changing source regions of magmas and crustal growth in the Tran-Himalayas: evidence from the Chalt volcanics and Kohistan batholith, Kohistan, northern, Pakistan. Earth and Planetary Science Letters 102, 326341 .

Petterson, M.G., Windley, B.F., Sullivan, M., 1991. A petrological, chronological, structural and geochemical review of Kohistan batholith and its relationship to regional tectonics. Physical and Chemistry of the Earth 17, 47-71.

Prince, C., Harris, N., Vance, D., 2001. Fluid-enhanced melting during prograde metamorphism. Journal of the Geological Society 158(2), 233-241. 
Rahmati-Ilkchi, M., Jerabek, P., Faryad, S.W., Koyi, H.A., 2010. Mid-Cimmerian, Early Alpine and Late Cenozoic orogenic events in the Shotur Kuh metamorphic complex, Grate Kavir block, NE Iran. Tectonophysics 494, 101-117.

Rex, B.J., Searle, M.P., Tirrul, R., Crawford, M.B., Prior, D.J., Rex, D.C., Barnicoat, 1988. The geochemical and tectonic evolution of the central Karakoram, North Pakistan. Philosophical Transactions of the Royal Society of London A326, 229-225.

Rogers, J.J.W., Unrug, R., Sultan, M., 1995. Tectonic assembly of Gondwana. Journal of Geodynamics 19 (1), 1-34.

Rolland, Y., Picard, C., Pêcher, A., Carrio, E., Sheppard, S.M.F., Oddone, M., Villa, I.M., 2002. Presnece and geodynamic significance of Cambro-Ordovician series of SE Karakoram (N Pakistan). Geodinamica Acta 15, 1-21.

Schärer, U., 1984. The effect of initial ${ }^{230} \mathrm{Th}$ disequilibrium on young U-Pb ages: The Makalu case, Himalaya: Earth and Planetary Science Letters 67, 191-204. doi:10.1016/0012821X(84)90114-6.

Searle, M.P., Windley, B.F., Coward, M.P., Cooper, D.J.W., Rex, A.J., Rex, D., Tingdong, L., Xuchang, Jan, M.Q., Thakur, V.C., Kumar, S., 1987. The closing of Tethys and the tectonics of the Himalaya. Geological Society of America Bulletin 98, 678-701.

Searle, M.P., Rex, A.J., Tirrul, R., Rex, D.C., Barnicoat, A., Windley, B.F., 1989. Metamorphic, magmatic and tectonic evolution of the central Karakoram in the BiafoBaltoro-Hushe regions of N. Pakistan. Geological Society of America, Special Paper $232,47-73$.

Searle M.P., Noble, S., Hurford, A., Rex, D., 1999. Age of crustal melting, emplacement and exhumation history of the Shivling Leucogranite, Garhwal Himalaya. Geological Magazine 136, 513-52

Searle, M.P., Hacker, B.R., Bilham, R., 2001. The Hindu Kush seismic zone as a paradigm for the creation of ultrahigh-presssure diamond- and coestie-Bearing continental rocks. The Journal of Geology 109, 143-153.

Searle, M.P., Parrish, R.R., Thow, A.V., Noble, S., Phillips, R.J., Waters, D.J., 2010. Anatomy, age and evolution of a collisional mountain belt: the Baltoro granite batholith and Karakoram Metamorphic Complex, Pakistani Karakoram. Journal of Geological Society $167,183-202$.

Sengör, A.M.C., 1979. Mid-Mesozoic closure of Permo-Triassic Tethys and its implications. Nature 279, 590-593. 
Steiger R., Jäger E., 1977. Subcommission on geochronology: convention on the use of decay constants in geo-and cosmochronology. Earth Planetary Science Letter 36, 359362

Stern, C.R., Kligfield, R., Schelling, D., Virdi, N.S., Futa, K., Peterman, Z.E., Amini, H., 1989. The Bhagirathi lecucogranite of the High Himalaya (Garwal, India); Age, petrogenesis, and tectonic implicaitons. Geological Society of America, Special Paper $232,33-44$.

Sun, S.S., McDonough, W.F., 1989. Chemical and isotopic systematics of oceanic basalts: implications for mantle composition and processesGeological Society, London, Special Publications 42, 313-345,

Tahirkheli, R.A.K., Mattauer, M., Proust F., Tapponnier, P., 1979. The India Eurasia Suture Zone Northern Pakistan: Synthesis and interpretation of recent data at plate scale In: Farah, A., De Jong, K.A. (Eds.): Geodynamics of Pakistan. Geological Survey of Pakistan Quetta, 125-130

Whalen, J.B., Currie, K.L., Chappell, B.W., 1987. A-type granites: geochemical characteristics discrimination and petrogenesis. Contributions to Mineralogy and Petrology 95, 407-419.

White, A.J.R., Chappell, B.W., 1983. Granitoid types and their distribution in the Lachlan Fold Belt, southeastern Australia. Geological Society of America Memoir 159, 21-34.

Whitney D.L., Evan, B.W., 2010. Abbreviations form manes of rock-forming minerals. American Mineralogist 95, 185-187.

Wu, F.Y., Sun, D. Y., Li, H., Jahn, B.M., Wilde, S., 2002. A-type granites in northeastern China: age and geochemical constraints on their petrogenesis. Chemical Geology 187, $143-173$.

Wu, F.Y., Jahn, B.M., Wilde, S.A., Lo, C.H., Yui, T.F., Lin, Q., Ge, W.C., Sun, D.Y. 2003. Highly fractionated I-type granites in NE China (I): geochronology and petrogenesis. Lithos 66, 241-273.

Yang, F., Mao, J., Liu, F., Chai, F., Guo, Z., Zhou, G., Geng, X., Gao, J., 2010. Geochronology and geochemistry of the granites from the Mengku iron deposit Altay Mountains, northwest China: implications for its tectonic setting and metallogenesis. Australian Journal of Earth Sciences 57, 803-818.

Yang, S. Y., Jiang, S. Y., Jiang, Y. H., Zhao, K. D., Fan, H. H., 2011. Geochemical, zircon $\mathrm{U}-\mathrm{Pb}$ dating and $\mathrm{Sr}-\mathrm{Nd}-\mathrm{Hf}$ isotopic constraints on the age and petrogenesis of an Early Cretaceous volcanic-intrusive complex at Xiangshan, Southeast China. Mineralogy and Petrology 101, 21-48. 
Zafar, M., Murata, M., Khan, T., Ozawa, H., Nishimura, H., 2000. K-Ar biotite ages from Miocene post-collisional Garam Chashma leucogranite, eastern Hindukush Range (Trans-Himlayas), northwestern Pakistan. Journal of Mineralogical and Petrological Sciences 95, 101-106.

Zanchi, A., Poli, S., Fumagalli, P., Gaetani, M., 2000. Mantle exhumation along the Tirich Mir Fault Zone, NW Pakistan: pre-mid-Cretaceous accretion of the Karakoram terrane to the Asia margin. Geological Society, London, Special Publication 170, 237-252.

Zanchi, A., Zanchetta, S., Berra, F., Mattei, M., Garzanti, E., Molyneux, S., Nawa, A., Sabouri, J., 2009. The Eo-Cambrian (Late? Triassic) orogeny in North Iran. In: Brunett, M.F., Wilmsen, M., Granath, J.W. (eds) South Caspian to Central Iran Basins. The Geological Society, London, Special Publications 312, 31-55.

Zhang, L. Y., Ding, L., Pullen, A, Xu, Q., Liu, D.L., Cai, F.L., Yue, Y.H., Lai, Q.Z., Shi, R.D, Ducea, M.N., Kapp, P., Chapman, A., 2014. Age and geochemistry of western Hoh-Xil-Songpan-Ganzi granitoids, northern Tibet: Implicaitons for the Mesozoic closure of the Paleo-Tethys ocean. Lithos190-191, 328-348. 


\section{$+\mathrm{N}$}
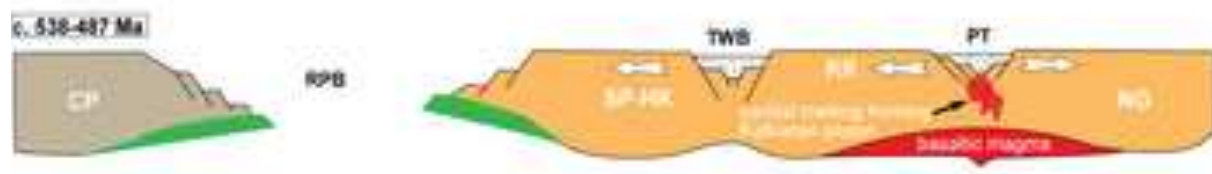

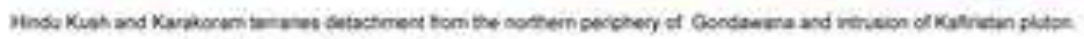

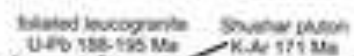

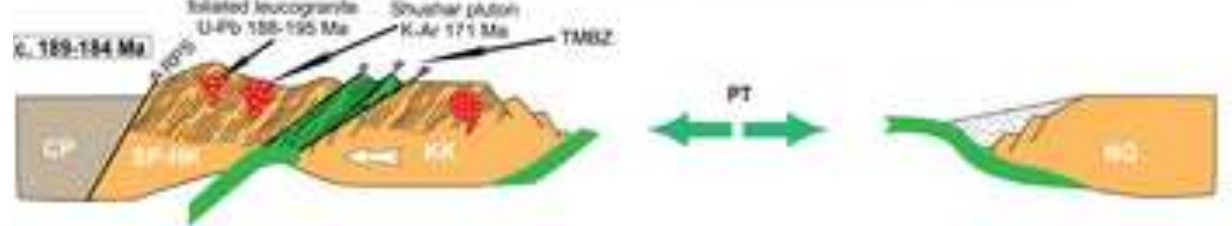

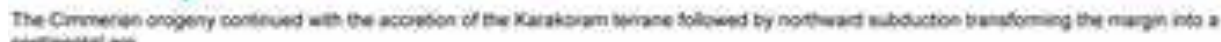

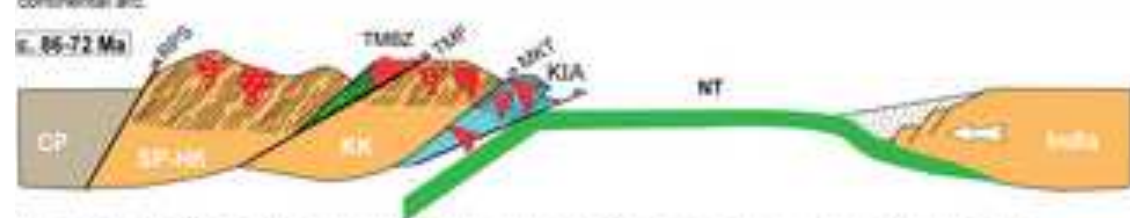

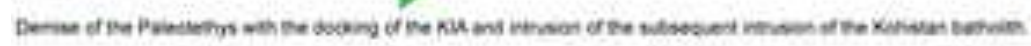

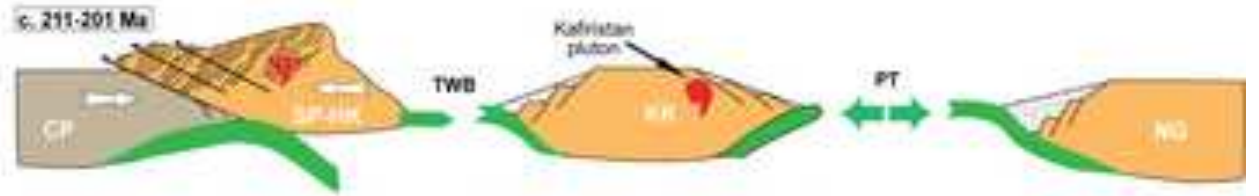

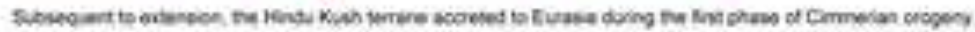

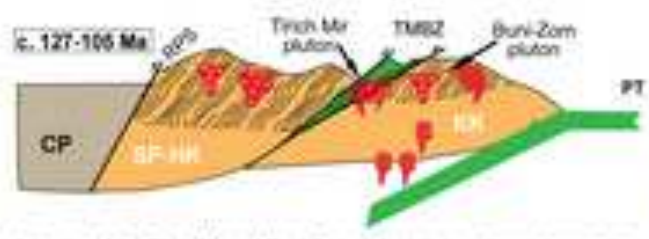

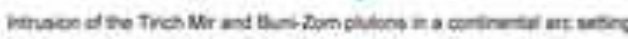
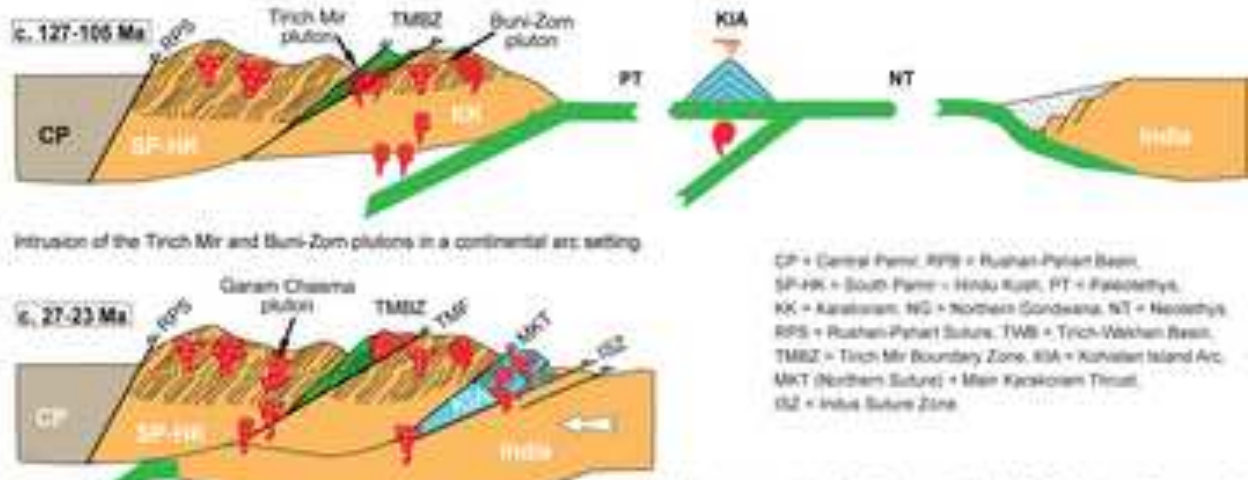

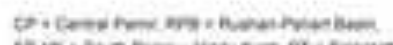

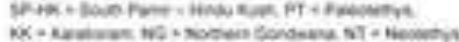

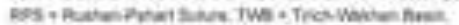

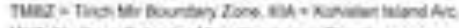

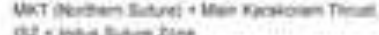

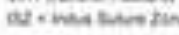




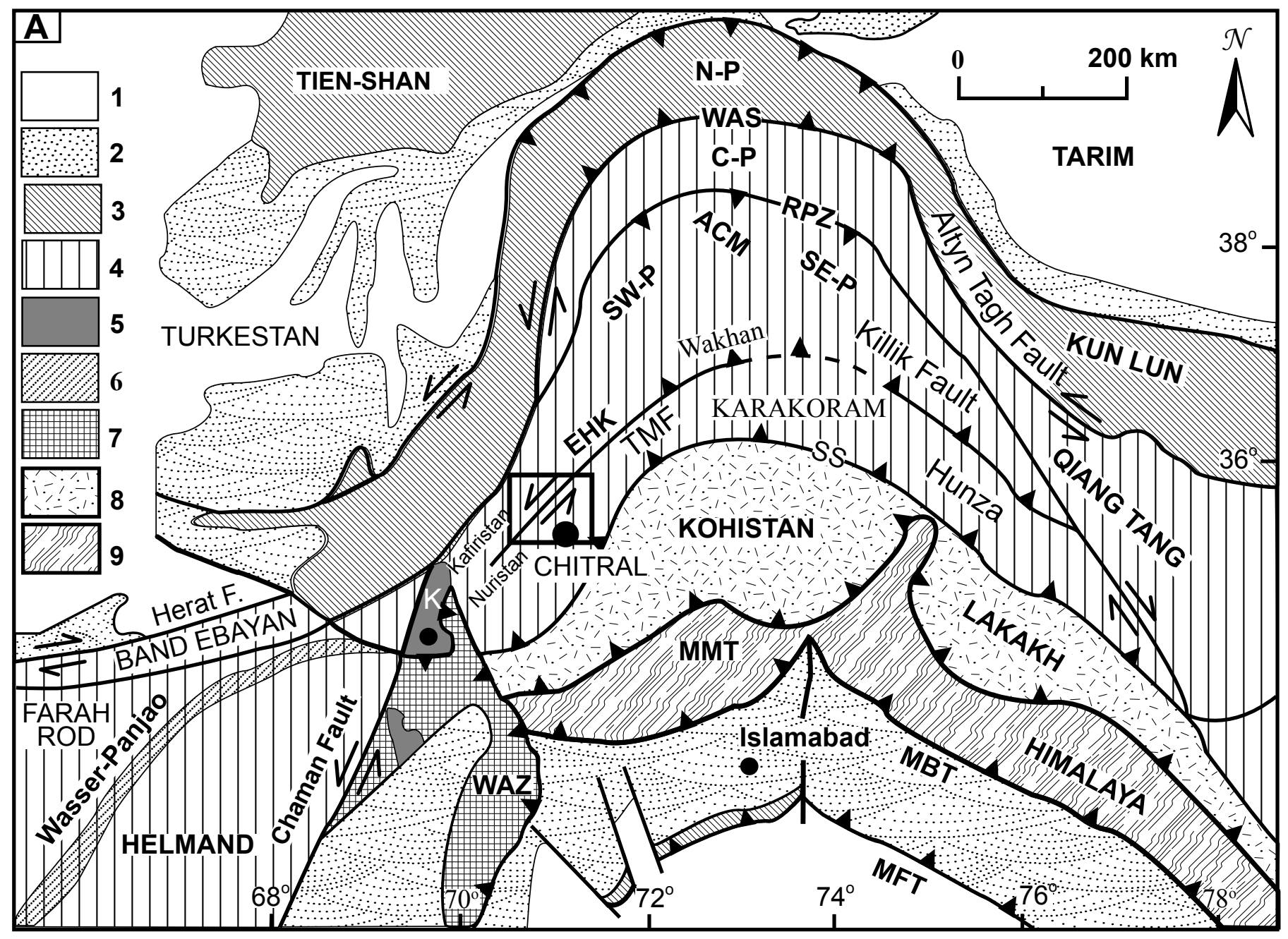




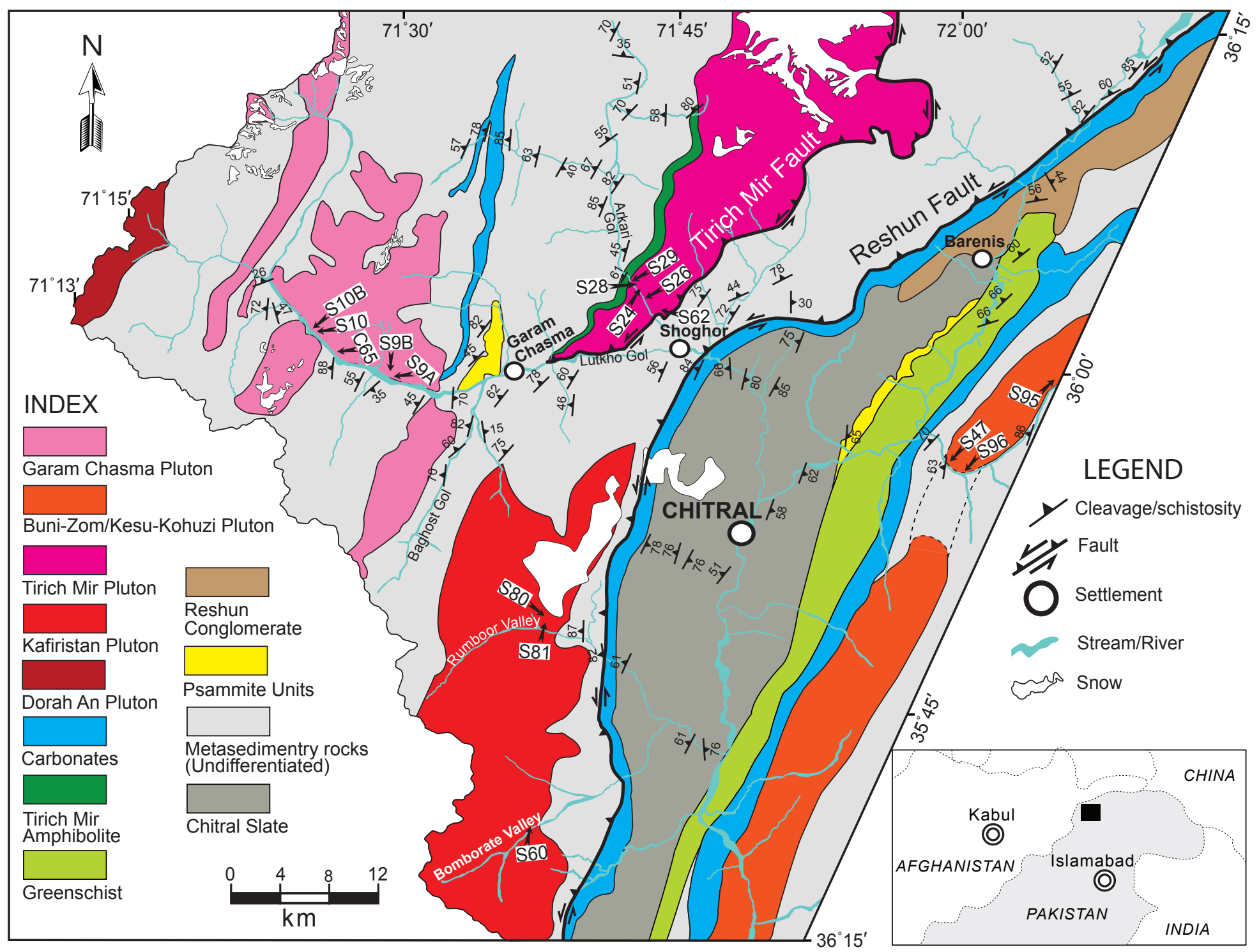



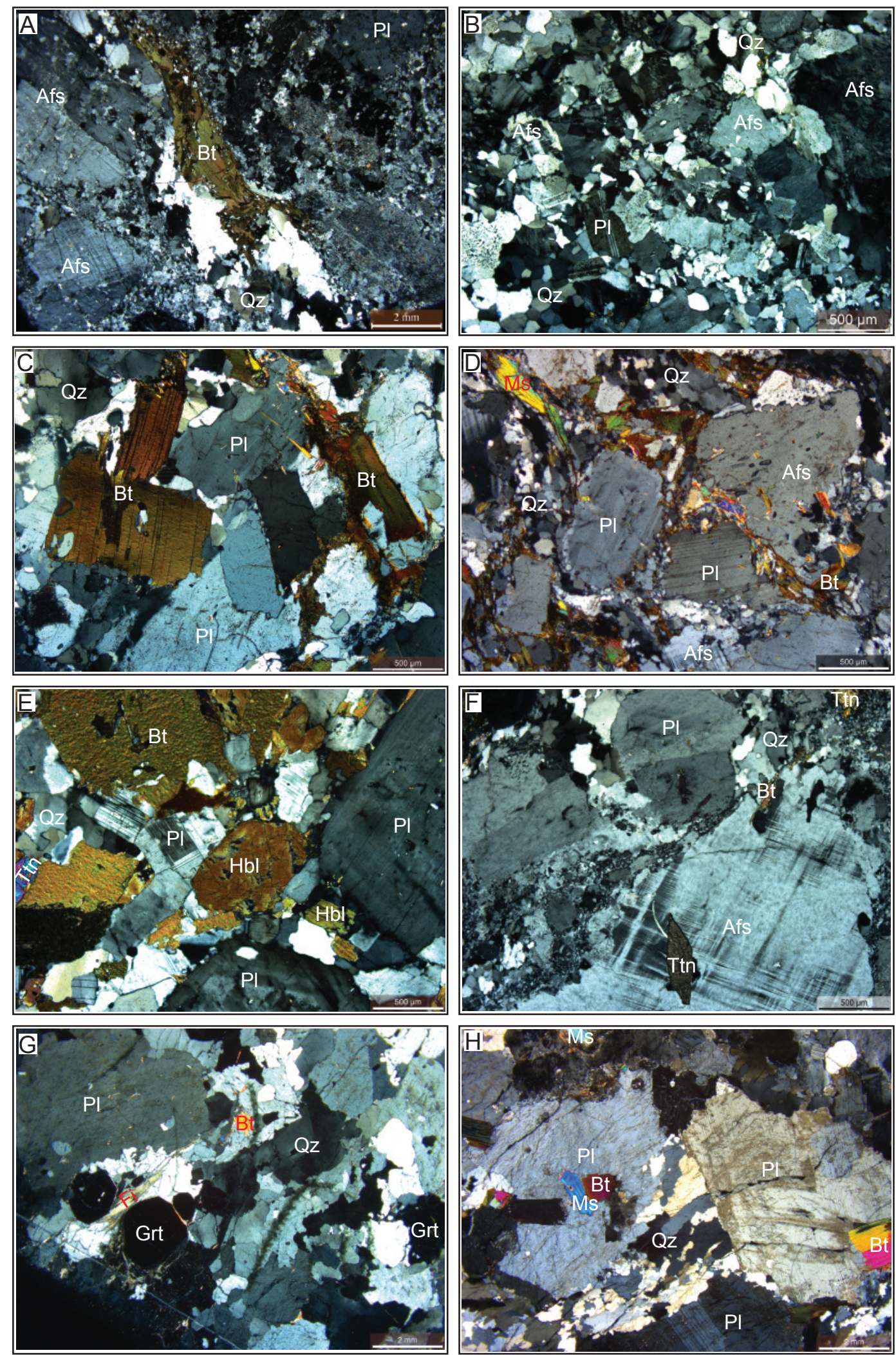


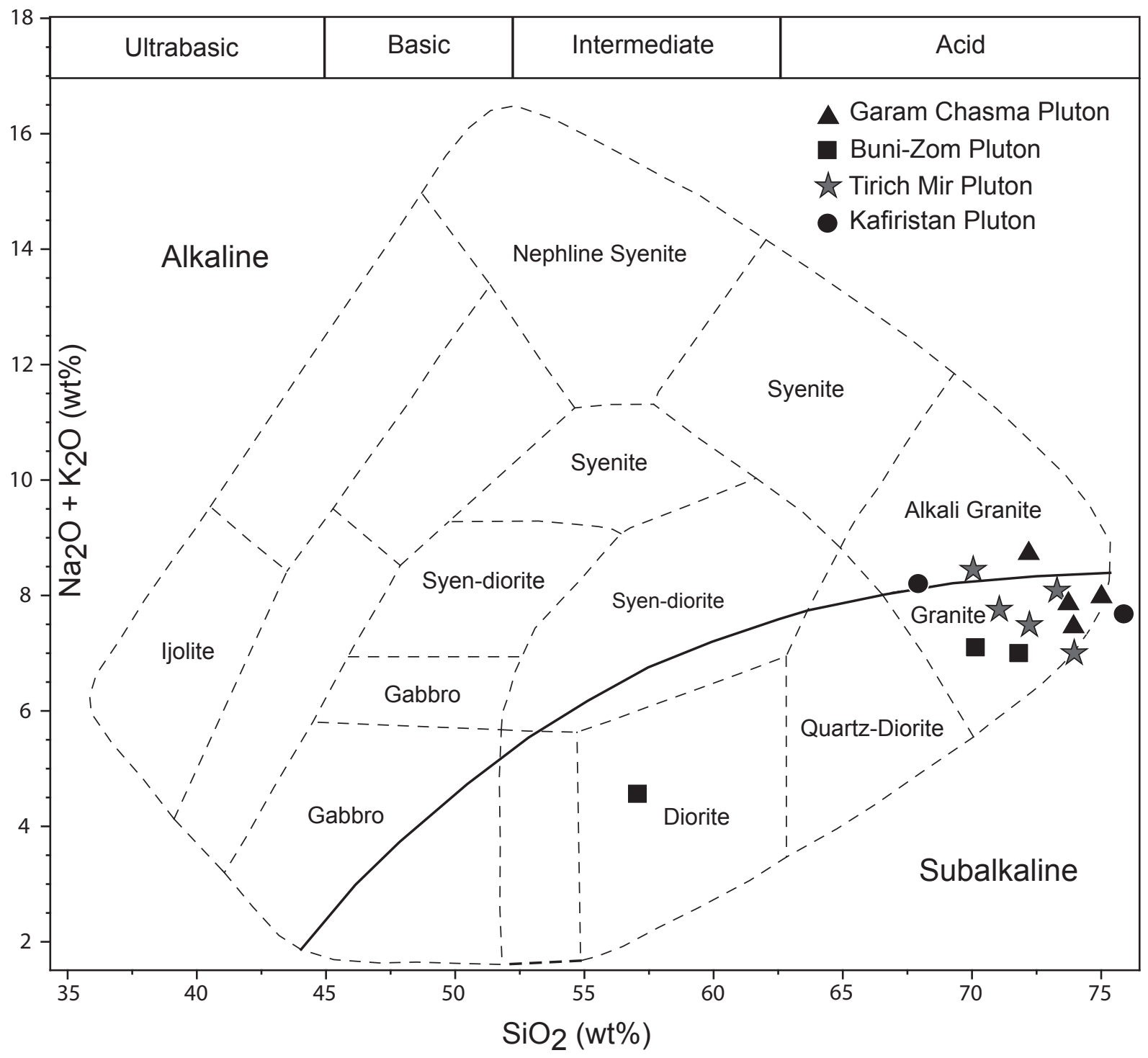



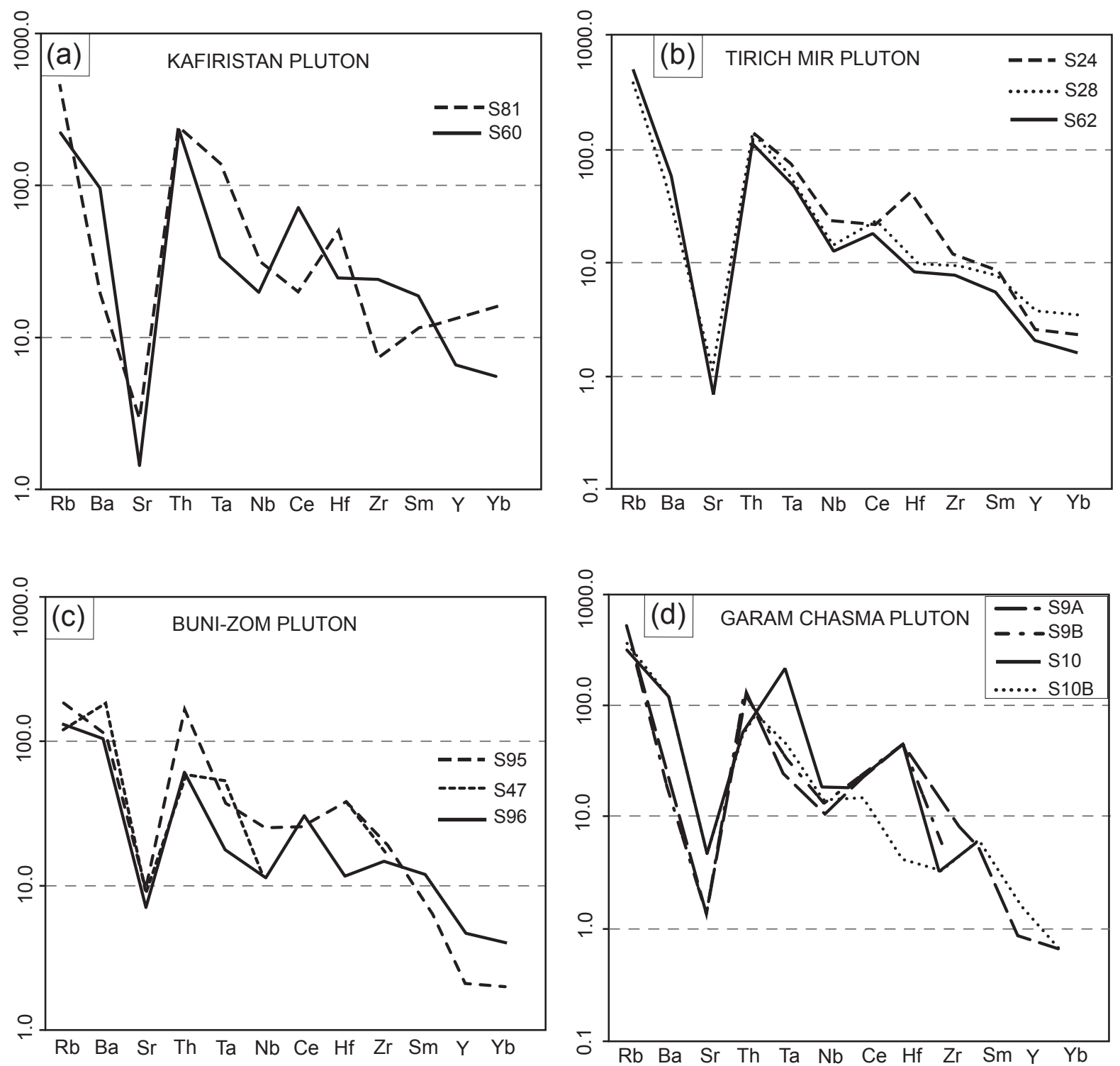

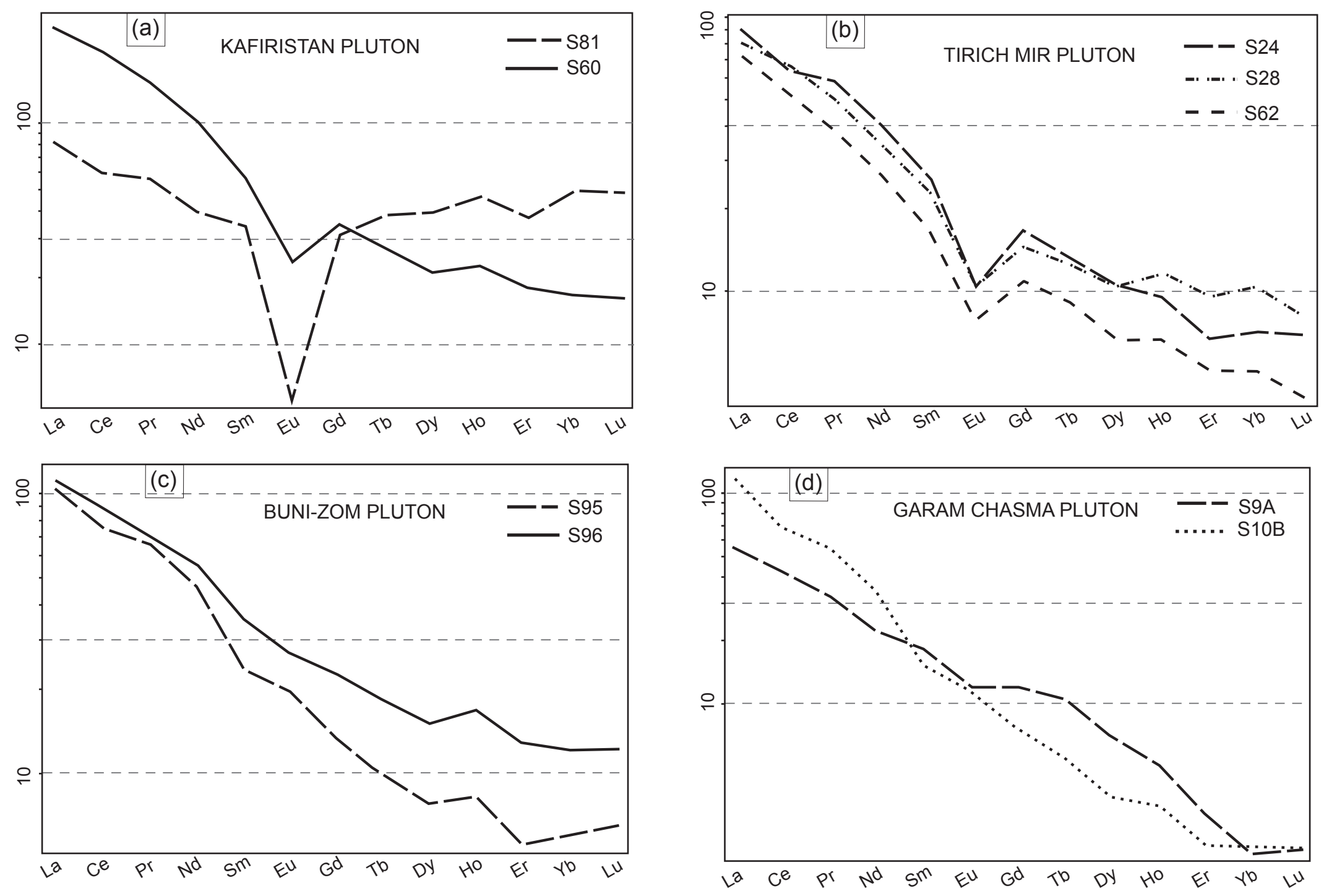


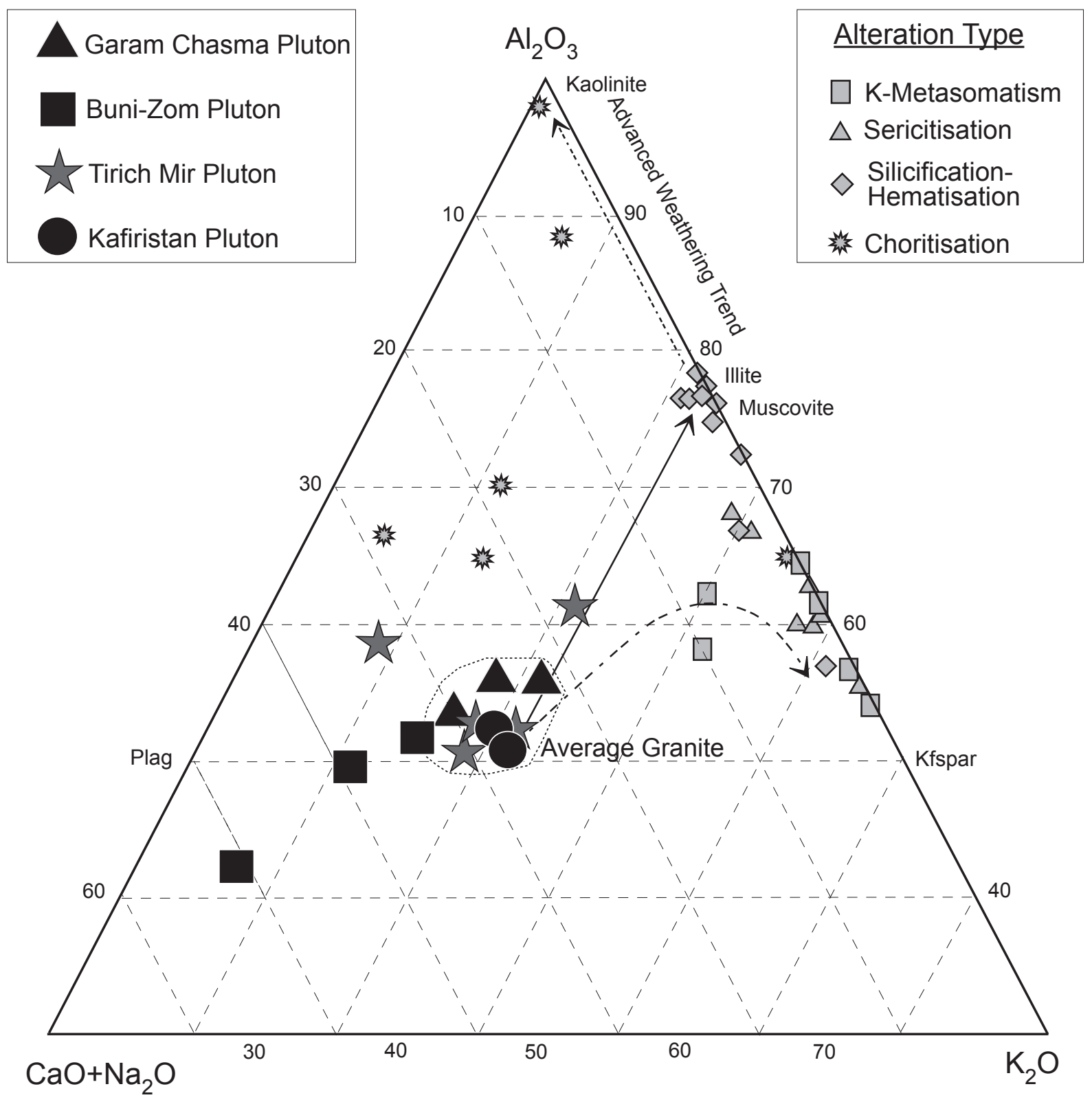



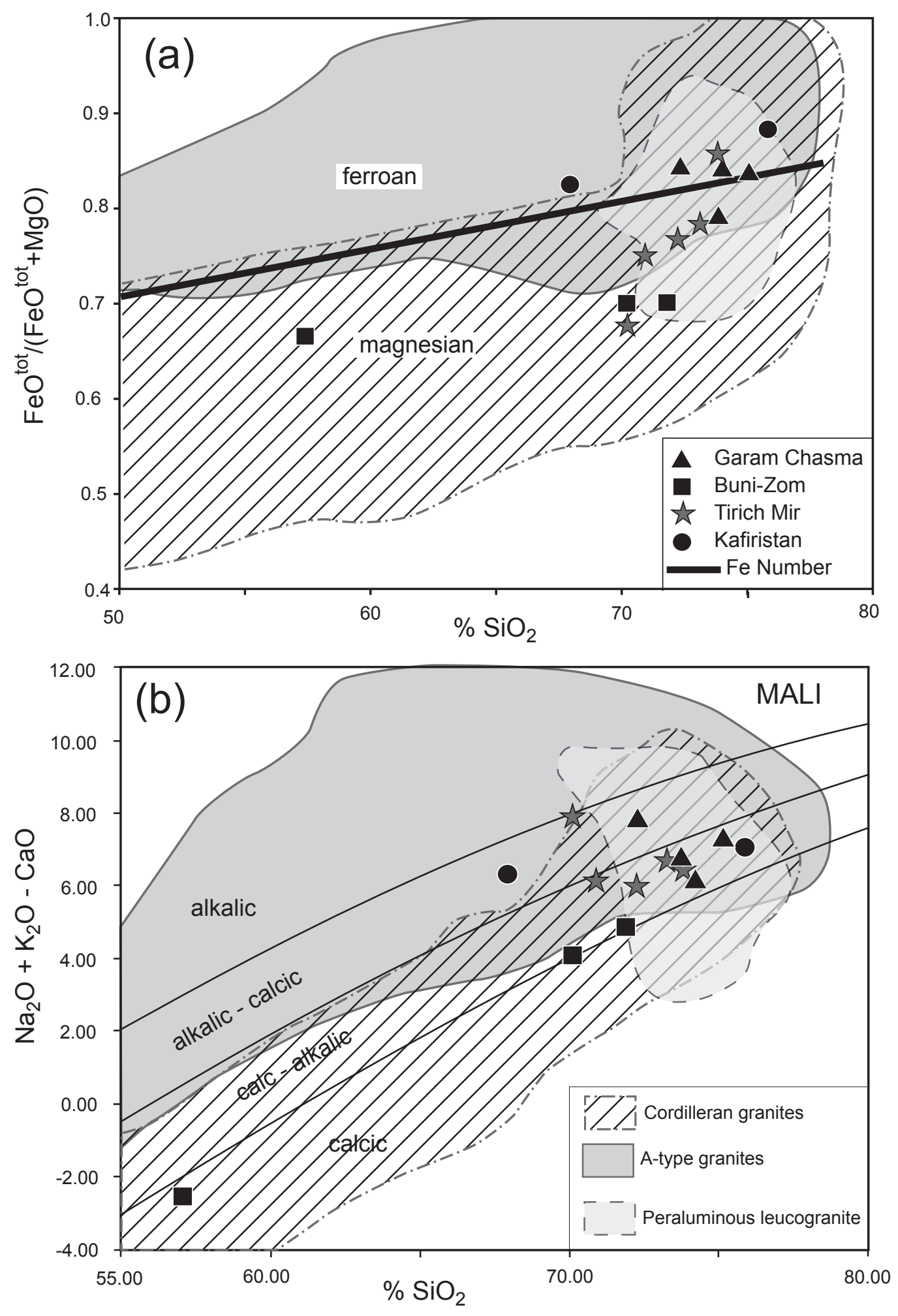


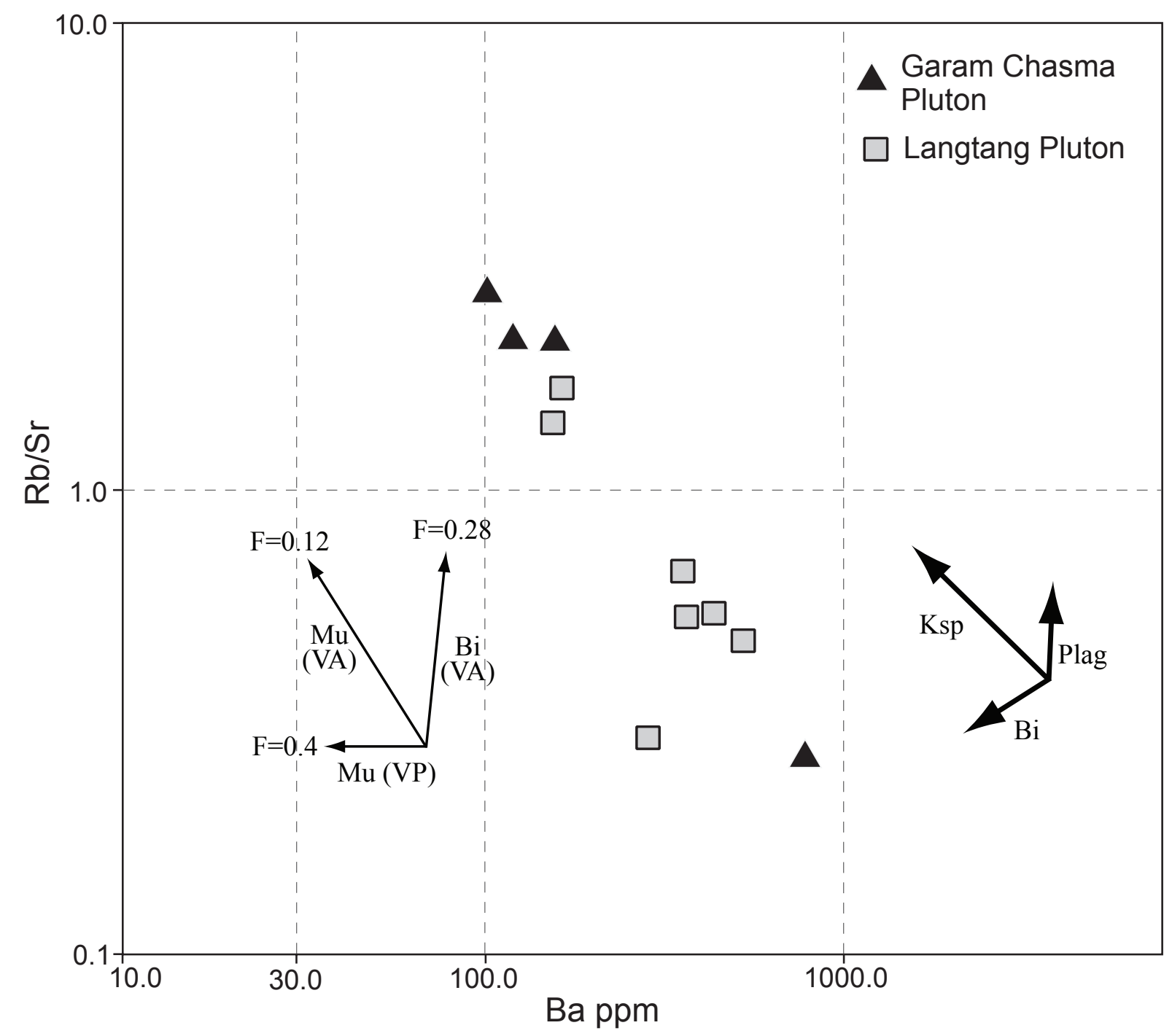



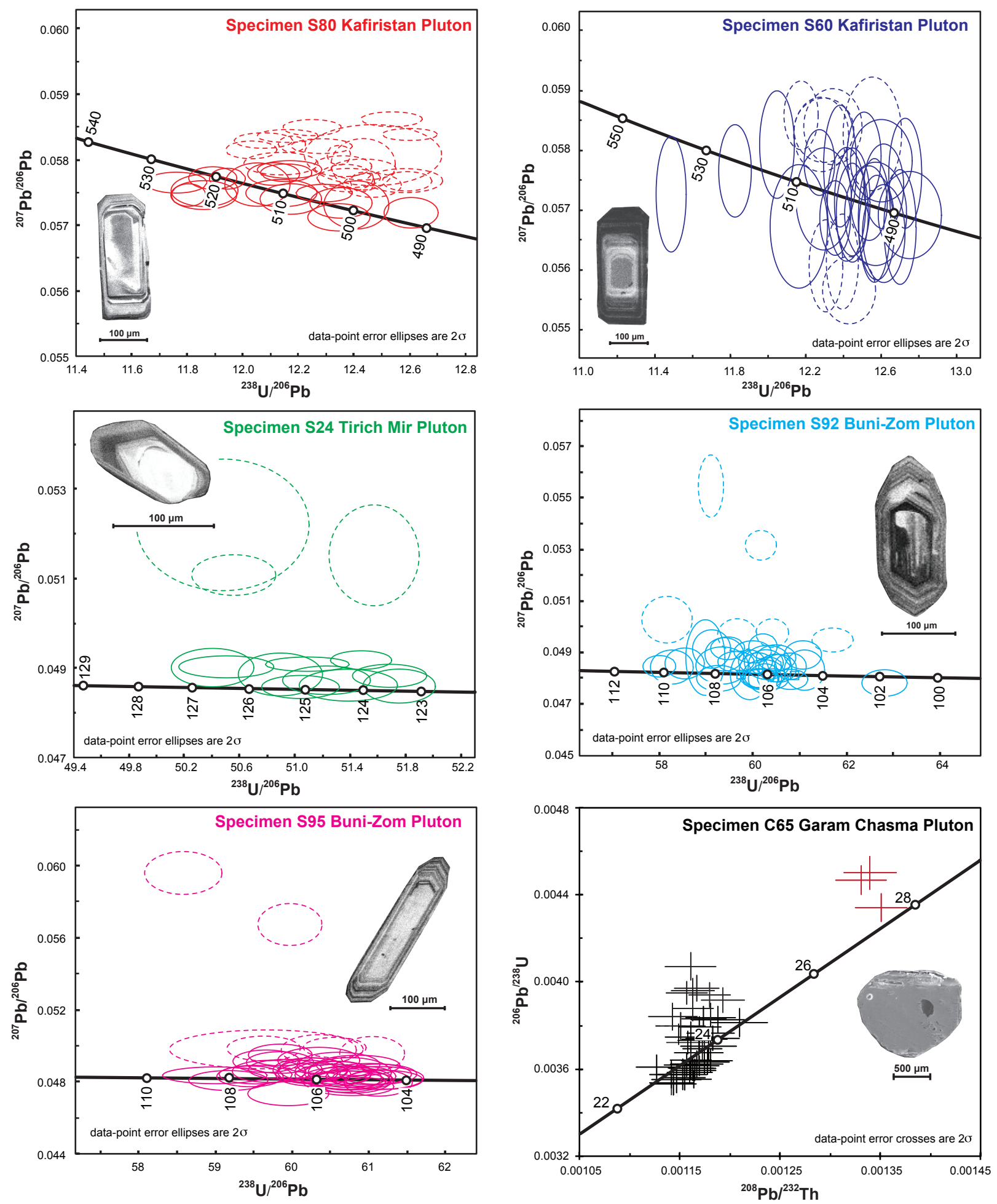
C. $538-487 \mathrm{Ma}$

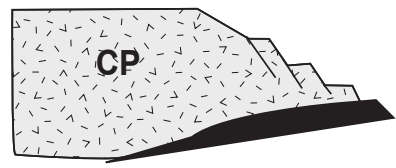

RPB

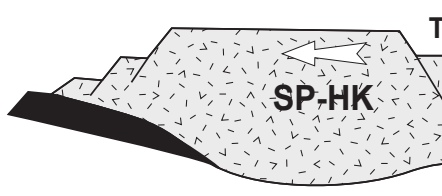

TWB

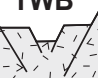

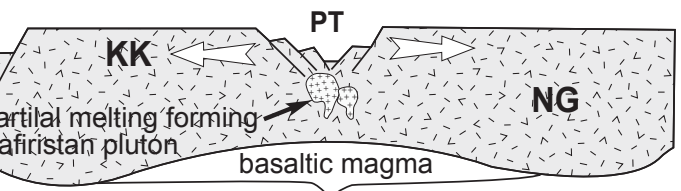

a) Hindu Kush and Karakoram terranes detachment from the northern periphery of Greater Gondawanland and intrusion of Kafiristan pluton at the same time during extensional tectonic settings.

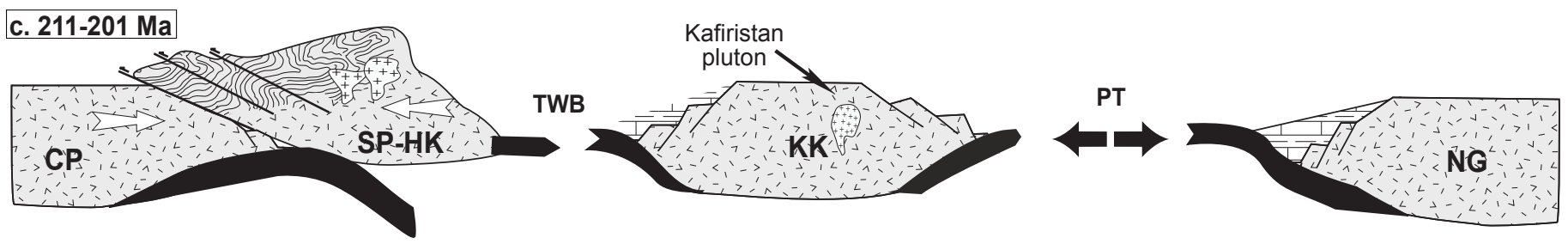

b) Subsequent to extension, the Hindu Kush terrane accreted to Eurasia during the first phase of Cimmerian orogeny.
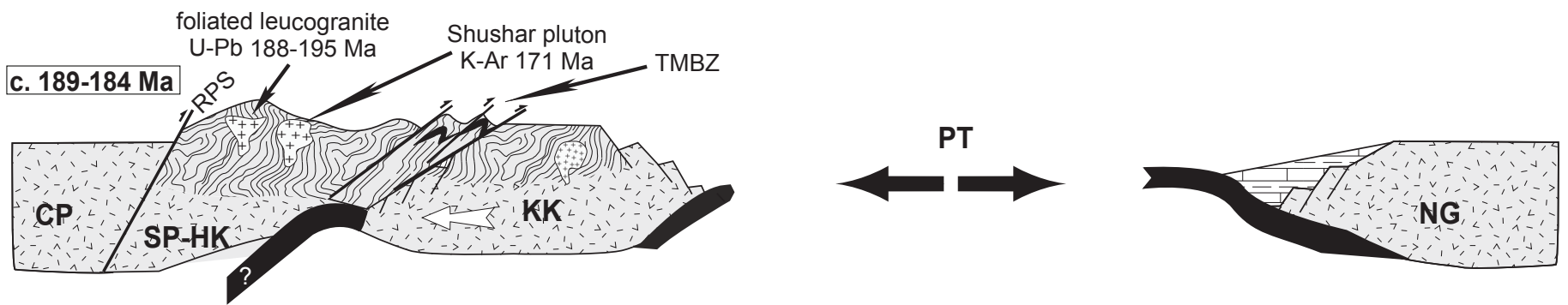

c) During the continous Cimmerian orogeny, the Karakoram accreted to Eurasia following the Hindu Kush, transforming the Eurasian margin into an Andean style.

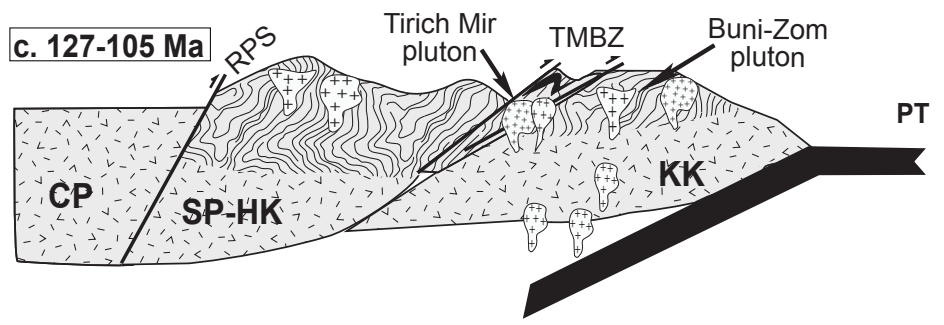

d) Intrusion of Tirich Mir and Buni-Zom in a Andean type-Eurasian margin.
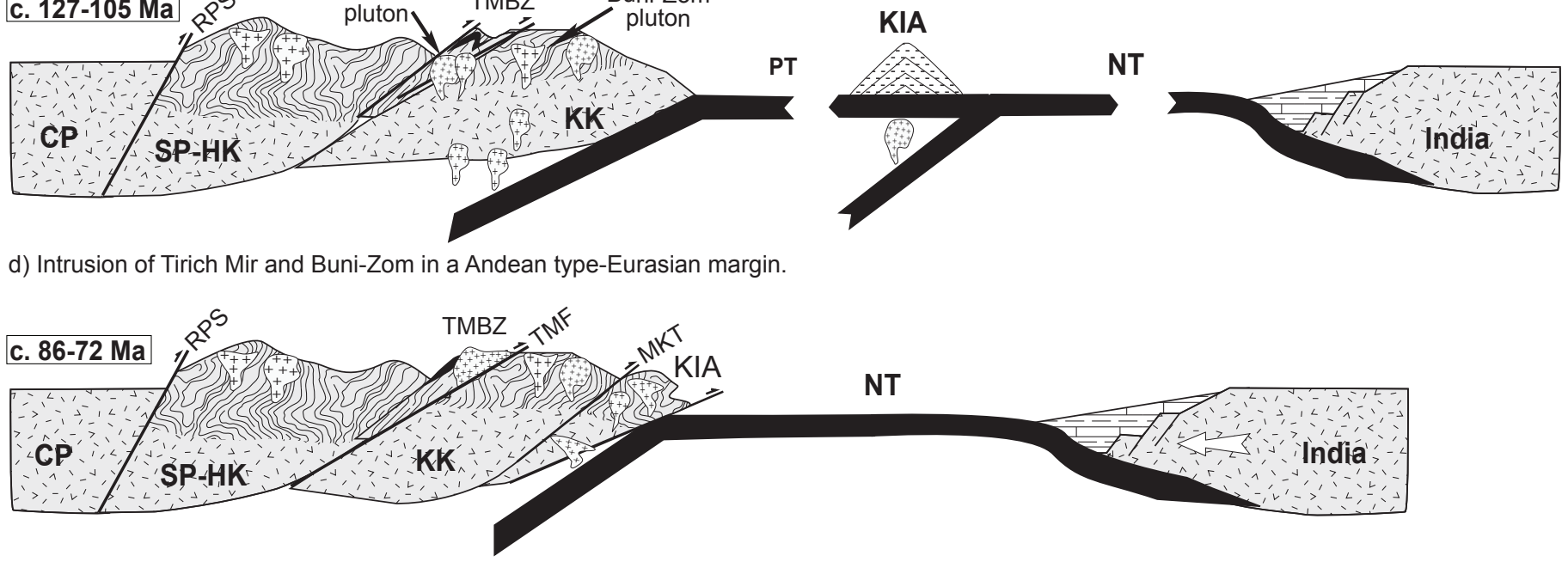

e) Demise of paleotethys with the docking of KIA and intrusion of the Kohistan batholith in a second Andean-type margin along Eurasia.

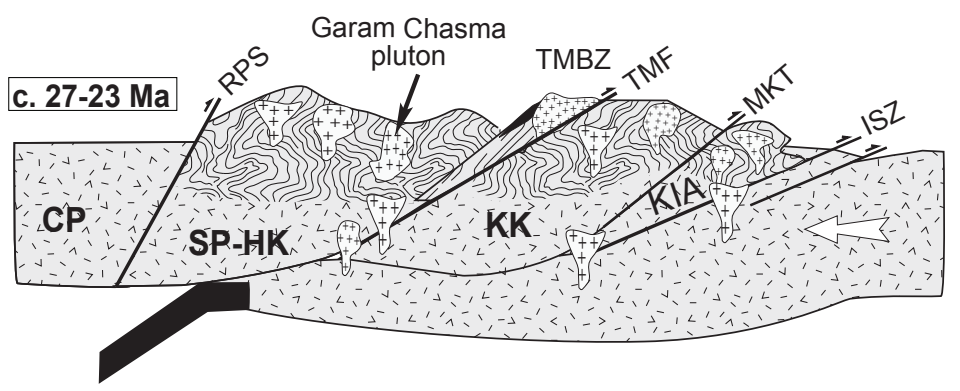

f) India-Eurasia collision is followed by the intrusion of Garam Chasma pluton due to anatexis of norhern margin of the Indian plate. 


\begin{tabular}{|c|c|c|c|c|c|c|c|c|c|c|c|c|c|}
\hline \multirow{2}{*}{ Samples } & \multicolumn{2}{|c|}{ Kafiristan } & \multicolumn{5}{|c|}{ Tirich Mir } & \multicolumn{3}{|c|}{ Buni-Zom } & \multicolumn{3}{|c|}{ Garam Chasm } \\
\hline & S-60 & S-81 & S-24 & S-26 & S-28 & S-29 & S-62 & $\mathrm{S}-47$ & S-95 & S-96 & S-9A & S-9B & S-10 \\
\hline $\mathrm{Na}_{2} \mathrm{O}$ & 2.53 & 3.26 & 2.84 & 4.83 & 3.62 & 2.72 & 2.18 & 3.46 & 3.96 & 2.49 & 3.33 & 2.61 & 3.26 \\
\hline $\mathrm{MgO}$ & 0.90 & 0.16 & 0.63 & 0.09 & 0.37 & 0.82 & 0.40 & 0.94 & 0.91 & 3.82 & 0.24 & 0.11 & 0.17 \\
\hline $\mathrm{Al}_{2} \mathrm{O}_{3}$ & 14.4 & 13.1 & 14.6 & 16.2 & 14.4 & 14.8 & 18.4 & 14.4 & 15.0 & 14.4 & 14.3 & 14.6 & 15.5 \\
\hline $\mathrm{SiO}_{2}$ & 67.9 & 75.9 & 72.2 & 73.9 & 73.2 & 71.0 & 70.0 & 71.8 & 70.1 & 57.1 & 74.1 & 75.0 & 73.7 \\
\hline $\mathrm{P}_{2} \mathrm{O}_{5}$ & 0.25 & 0.09 & 0.28 & 0.19 & 0.17 & 0.30 & 0.22 & 0.20 & 0.26 & 0.43 & 0.08 & 0.10 & 0.17 \\
\hline $\mathrm{K}_{2} \mathrm{O}$ & 5.70 & 4.48 & 4.57 & 2.17 & 4.57 & 5.04 & 6.22 & 3.55 & 3.14 & 2.08 & 4.11 & 5.39 & 4.59 \\
\hline $\mathrm{CaO}$ & 1.92 & 0.69 & 1.37 & 0.60 & 1.50 & 1.61 & 0.55 & 2.10 & 2.98 & 7.12 & 1.32 & 0.69 & 1.09 \\
\hline $\mathrm{TiO}_{2}$ & 0.67 & 0.15 & 0.39 & 0.02 & 0.23 & 0.46 & 0.43 & 0.33 & 0.38 & 1.12 & 0.21 & 0.08 & 0.11 \\
\hline $\mathrm{MnO}$ & 0.08 & 0.02 & 0.05 & 0.10 & 0.03 & 0.04 & 0.02 & 0.04 & 0.05 & 0.16 & 0.01 & 0.02 & 0.01 \\
\hline $\mathrm{Fe}_{2} \mathrm{O}_{3}$ & 4.76 & 1.29 & 2.32 & 0.590 & 1.51 & 2.77 & 0.94 & 2.36 & 2.27 & 8.65 & 1.41 & 0.63 & 0.71 \\
\hline Total & 99.1 & 99.1 & 99.3 & 98.7 & 99.6 & 99.5 & 99.4 & 99.2 & 99.1 & 97.4 & 99.1 & 99.2 & 99.3 \\
\hline $\mathrm{S}$ & 0.01 & 0.01 & 0.01 & 0.01 & 0.01 & 0.01 & 0.01 & 0.01 & 0.01 & 0.01 & 0.01 & 0.01 & 0.01 \\
\hline $\mathrm{Sc}$ & 7.90 & 3.10 & 5.10 & 1.50 & 1.50 & 7.80 & 5.70 & 2.50 & 4.00 & 22.0 & 1.50 & 4.60 & 1.50 \\
\hline $\mathrm{V}$ & 44.0 & 0.80 & 19.6 & 0.50 & 5.40 & 26.3 & 16.2 & 26.4 & 32.1 & 191.8 & 0.80 & 0.50 & 0.50 \\
\hline $\mathrm{Cr}$ & 18.2 & 12.4 & 10.9 & 43.8 & 19.4 & 24.7 & 23.3 & 16.9 & 31.1 & 22.2 & 17.9 & 6.6 & 17.2 \\
\hline Co & 2.30 & 1.50 & 1.50 & 1.50 & 2.30 & 1.50 & 5.80 & 1.50 & 1.50 & 25.8 & 1.50 & 1.50 & 1.50 \\
\hline $\mathrm{Ni}$ & 7.2 & 9.2 & 7.6 & 10.7 & 8.3 & 14.0 & 13.1 & 10.0 & 12.4 & 22.0 & 9.7 & 8.5 & 11.0 \\
\hline $\mathrm{Cu}$ & 22.8 & 2.5 & 2.5 & 2.5 & 3.4 & 2.5 & 4.0 & 2.5 & 2.5 & 17.7 & 2.5 & 2.5 & 16.8 \\
\hline $\mathrm{Zn}$ & 55.9 & 12.1 & 68.0 & 17.3 & 38.5 & 72.4 & 2.30 & 47.6 & 56.6 & 89.2 & 46.2 & 17.0 & 45.1 \\
\hline $\mathrm{Ga}$ & 18.5 & 21.0 & 21.7 & 24.5 & 19.9 & 21.3 & 18.6 & 18.9 & 21.2 & 17.8 & 19.7 & 22.4 & 28.3 \\
\hline As & 2.30 & 1.5 & 1.5 & 1.5 & 1.5 & 1.5 & 2.9 & 1.5 & 1.5 & 0.9 & 1.5 & 1.5 & 0.5 \\
\hline $\mathrm{Se}$ & 5.0 & 22.3 & 5.0 & 44.4 & 13.8 & 5.00 & 26.5 & 5.0 & 5.0 & 5.0 & 18.7 & 22.7 & 28.0 \\
\hline $\mathrm{Br}$ & 4.0 & 14.9 & 10.5 & 23.4 & 13.3 & 8.1 & 17.6 & 11.1 & 5.0 & 5.0 & 14.6 & 15.0 & 17.5 \\
\hline $\mathrm{Rb}$ & 127 & 285 & 295 & 221 & 229 & 288 & 279 & 68.4 & 103 & 73.5 & 209 & 274 & 329 \\
\hline $\mathrm{Sr}$ & 131 & 60.8 & 104 & 15.7 & 84.0 & 144 & 62.0 & 826 & 809 & 619 & 395 & 128 & 161 \\
\hline $\mathrm{Zr}$ & 268 & 81.3 & 126 & 7.8 & 104 & 175 & 87 & 197 & 226 & 165 & 147 & 66.7 & 36.1 \\
\hline Mo & 2.0 & 1.0 & 2.0 & 5.0 & 1.7 & 3.0 & 2.1 & 1.0 & 2.0 & 2.3 & 11.0 & 6.0 & 6.0 \\
\hline $\mathrm{Sn}$ & 2.20 & 6.5 & 1.5 & 23.2 & 7.5 & 1.5 & 10.6 & 1.5 & 1.5 & 1.8 & 1.5 & 6.6 & 9.5 \\
\hline $\mathrm{Sb}$ & 1.00 & 9.7 & 3.8 & 5.8 & 1.0 & 8.0 & 6.9 & 1.0 & 1.0 & 1.0 & 1.0 & 2.9 & 4.0 \\
\hline Cs & 2.2 & 7.2 & 11.9 & 2.5 & 7.7 & 5.7 & 3.8 & 2.5 & 5.1 & 0.7 & 5.3 & 11.6 & 2.5 \\
\hline $\mathrm{Ba}$ & 619 & 138 & 226 & 2.5 & 212 & 298 & 358 & 1147 & 717 & 631 & 773 & 103 & 158 \\
\hline $\mathrm{Hf}$ & 7.5 & 15.4 & 13.2 & 17.8 & 3.1 & 12.3 & 2.6 & 12.0 & 11.6 & 3.6 & 13.9 & 14.1 & 13.8 \\
\hline W & 5.0 & 32.8 & 17.4 & 43.5 & 20.4 & 5.0 & 35.6 & 18.9 & 10.6 & 5.0 & 32.0 & 33.1 & 26.9 \\
\hline $\mathrm{Pb}$ & 28.0 & 27.0 & 50.0 & 32.9 & 53.1 & 49.7 & 44.6 & 22.2 & 24.9 & 7.60 & 58.9 & 74.6 & 89.8 \\
\hline $\mathrm{Bi}$ & 2.5 & 18.5 & 13.6 & 50.4 & 23.7 & 2.5 & 31.6 & 16.8 & 6.7 & 2.5 & 22.5 & 27.9 & 35.4 \\
\hline $\mathrm{Ce}$ & 128 & 36.0 & 39.0 & & 41.0 & & 32.0 & & 46.0 & 54.0 & 42.0 & & \\
\hline Dy & 5.16 & 9.67 & 2.57 & & 2.55 & & 1.64 & & 1.92 & 3.69 & 0.89 & & \\
\hline $\mathrm{Er}$ & 2.88 & 6.06 & 1.08 & & 1.53 & & 0.82 & & 0.89 & 2.05 & 0.34 & & \\
\hline $\mathrm{Eu}$ & 1.32 & 0.31 & 0.58 & & 0.59 & & 0.44 & & 1.10 & 1.51 & 0.64 & & \\
\hline $\mathrm{Gd}$ & 6.87 & 6.20 & 3.30 & & 2.87 & & 2.18 & & 2.64 & 4.50 & 1.53 & & \\
\hline Но & 1.23 & 2.54 & 0.52 & & 0.63 & & 0.36 & & 0.45 & 0.92 & 0.18 & & \\
\hline $\mathrm{La}$ & 63.0 & 19.0 & 21.0 & 2.50 & 19.0 & 19.0 & 17.0 & 21.0 & 24.0 & 26.0 & 27.0 & 13.0 & 10.0 \\
\hline $\mathrm{Lu}$ & 0.40 & 1.20 & 0.17 & & 0.20 & & 0.10 & & 0.16 & 0.30 & 0.05 & & \\
\hline $\mathrm{Nb}$ & 14.0 & 22.2 & 16.0 & 22.0 & 10.0 & 17.6 & 9.00 & 8.10 & 18.0 & 8.00 & 7.0 & 11.0 & 9.7 \\
\hline $\mathrm{Nd}$ & 46.3 & 18.1 & 18.3 & & 15.6 & & 11.9 & & 21.1 & 25.2 & 15.5 & & \\
\hline $\operatorname{Pr}$ & 14.00 & 5.19 & 5.38 & & 4.55 & & 3.54 & & 6.10 & 6.46 & 5.03 & & \\
\hline $\mathrm{Sm}$ & 8.40 & 5.09 & 3.80 & & 3.36 & & 2.48 & & 3.52 & 5.24 & 2.26 & & \\
\hline $\mathrm{Ta}$ & 1.37 & 5.80 & 2.96 & 4.72 & 2.36 & 2.76 & 1.96 & 2.16 & 1.56 & 0.72 & 0.98 & 1.50 & 9.10 \\
\hline
\end{tabular}




\begin{tabular}{|c|c|c|c|c|c|c|c|c|c|c|c|c|c|c|c|}
\hline \multirow[b]{2}{*}{$\begin{array}{c}\text { Sample } \\
\text { Name }\end{array}$} & \multicolumn{5}{|c|}{ Concentration (ppm) } & \multicolumn{3}{|c|}{ Measured Isotopic Ratios } & \multicolumn{7}{|c|}{ Measured Isotopic Ages } \\
\hline & $\mathbf{U}$ & Th & $\mathbf{P b}$ & $\mathbf{T h} / \mathbf{U}$ & $\begin{array}{l}{ }^{207} \mathrm{~Pb} /{ }^{206} \\
\mathrm{~Pb}\end{array}$ & $2 \mathrm{~s} \%$ & ${ }^{207} \mathrm{~Pb} /{ }^{235} \mathrm{U}$ & $2 \mathrm{~s} \%$ & $\begin{array}{l}{ }_{\mathrm{U}}^{206} \mathrm{~Pb} /{ }^{238} \\
\end{array}$ & $2 \mathrm{~s} \%$ & Rho & $\begin{array}{l}{ }^{206} \mathrm{~Pb} /{ }^{2} \\
{ }^{38} \mathrm{U}\end{array}$ & 2s abs & $\begin{array}{l}{ }^{207} \mathrm{~Pb} \\
\text { corrected } \\
{ }^{206} \mathrm{~Pb} /{ }^{238} \mathrm{U} \\
\text { date }\end{array}$ & $\begin{array}{l}2 s \\
\text { abs }\end{array}$ \\
\hline S80_01 & 450 & 246 & 55 & 0.55 & 0.05719 & 0.332 & 0.62650 & 0.670 & 0.07933 & 0.630 & 0.87 & 492.1 & 3.0 & 492.0 & 3.2 \\
\hline S80_02 & 904 & 260 & 59 & 0.29 & 0.05712 & 0.298 & 0.63670 & 0.770 & 0.08100 & 0.741 & 0.91 & 502.1 & 3.6 & 502.2 & 3.8 \\
\hline S80_03 & 3191 & 360 & 106 & 0.11 & 0.05807 & 0.654 & 0.64100 & 1.872 & 0.08020 & 1.621 & 0.97 & 497.3 & 7.6 & 496.8 & 8.3 \\
\hline S80_04 & 190 & 34 & 9 & 0.18 & 0.05580 & 2.151 & 0.51100 & 6.654 & 0.06770 & 3.840 & 0.96 & 422.0 & 16.0 & 422.0 & 16.6 \\
\hline S80_05 & 2215 & 409 & 95 & 0.19 & 0.05749 & 0.191 & 0.64250 & 0.763 & 0.08135 & 0.676 & 0.97 & 504.2 & 3.3 & 504.1 & 3.5 \\
\hline S80_06 & 1427 & 442 & 101 & 0.31 & 0.05785 & 0.225 & 0.64070 & 0.812 & 0.08042 & 0.771 & 0.96 & 498.6 & .7 & 498.2 & 3.9 \\
\hline S80_07 & 2025 & 381 & 88 & 0.19 & 0.05785 & 0.190 & 0.65390 & 0.811 & 0.08218 & 0.779 & 0.97 & 509.1 & 3.8 & 508.9 & 4.1 \\
\hline S80_08 & 612 & 145 & 35 & 0.24 & 0.05740 & 0.331 & 0.64910 & 0.739 & 0.08 & 0.743 & 0.88 & 508.9 & 3.6 & 509.0 & 3.9 \\
\hline S80_09 & 3199 & 435 & 101 & 0.14 & 0.05821 & 0.158 & 0.65120 & 0.691 & 0.08141 & 0.737 & 0.97 & 504.5 & 3.6 & 504.0 & 3.8 \\
\hline S80_10 & 3123 & 512 & 119 & 0.17 & 0.05849 & 0.171 & 0.65750 & 0.745 & 0.08164 & 0.698 & 0.97 & 505.9 & 3.4 & 505.2 & 3.6 \\
\hline S80_11 & 894 & 250 & 57 & 0.28 & 0.05772 & 0.295 & 0.64350 & 0.808 & 0.08084 & 0.656 & 0.92 & 501.1 & .2 & 500.8 & 3.4 \\
\hline S80_12 & 1028 & 341 & 81 & 0.34 & 0.05772 & 0.243 & 0.66740 & 0.674 & 0.08409 & 0.595 & 0.94 & 520.5 & 3.0 & 520.5 & 3.2 \\
\hline S80_13 & 2578 & 620 & 146 & 0.24 & 0.05815 & 0.189 & 0.66520 & 0.676 & 0.08312 & 0.626 & 0.97 & 514.7 & .1 & 4.4 & 3.3 \\
\hline S80_14 & 1430 & 302 & 68 & 0.21 & 0.05790 & 0.225 & 0.64450 & 0.652 & 0.08091 & 0.692 & 0.93 & 501.6 & 3.3 & 01.2 & 3.6 \\
\hline S80_15 & 278 & 147 & 33 & 0.53 & 0.05793 & 0.552 & 64290 & 0.855 & 0.08043 & 0.758 & 0.80 & 498.7 & 3.6 & 498.2 & 3.9 \\
\hline S80_16 & 1866 & 407 & 93 & 0.22 & 0.05778 & 0.242 & 5710 & 0.730 & 257 & 0.630 & 0.94 & 511.4 & .1 & 511.3 & 3.3 \\
\hline S80_17 & 368 & 186 & 42 & 0.50 & 0.05731 & 0.523 & 0.63650 & 0.943 & 0.08059 & 0.769 & 0.81 & 499.6 & 3.7 & 499.6 & 3.9 \\
\hline S80_18 & 1955 & 477 & 106 & 0.24 & 0.05767 & 0.208 & 0.63290 & 0.695 & 0.07942 & 0.579 & 0.74 & 492.7 & .7 & 2.3 & 2.9 \\
\hline S80_19 & 460 & 267 & 64 & 0.58 & 0.05753 & 0.348 & 0.66700 & 0.885 & 0.08430 & 0.830 & 0.91 & 521.7 & 4.1 & 521.9 & 4.5 \\
\hline S80_20 & 1055 & 376 & 85 & 0.36 & 0.05749 & 0.296 & 200 & 0.936 & & 0.862 & 0.94 & 510.3 & .2 & 10.3 & 4.5 \\
\hline S80_21 & 1147 & 285 & 67 & 0.25 & 0.05746 & 0.313 & 0.66830 & 0.793 & 0.08432 & 0.818 & 0.92 & 521.8 & 4.1 & 522.1 & 4.4 \\
\hline S80_22 & 3880 & 463 & 105 & 0.12 & 0.05862 & 0.157 & 0.64280 & 0.747 & 0.07977 & 0.715 & 0.98 & 494.8 & 4 & 3.8 & 3.6 \\
\hline S80_23 & 4493 & 572 & 124 & 0.13 & 0.05839 & 0.127 & 0.63730 & 0.643 & 0.07936 & 0.643 & 0.98 & 492.3 & 3.1 & 491.5 & 3.2 \\
\hline S80_24 & 4110 & 982 & 215 & 0.24 & 0.05836 & 0.137 & 0.66050 & 0.742 & 0.08223 & 0.742 & 0.98 & 509.4 & 3.6 & 508.9 & 3.9 \\
\hline S80_25 & 1589 & 372 & 85 & 0.24 & 0.05794 & 0.242 & 0.65730 & 0.898 & 239 & 0.898 & 0.97 & 510.3 & .4 & 10.1 & 4.7 \\
\hline S80_26 & 451 & 254 & 57 & 0.56 & 0.05762 & 0.469 & 00 & 0.865 & & 0.795 & 0.85 & 513.8 & .9 & 3.8 & 4.2 \\
\hline S80_27 & 1295 & 333 & 73 & 0.26 & 0.05761 & 0.260 & 0.63670 & 0.754 & 0.08022 & 0.686 & 0.83 & 497.4 & 3 & 497.2 & 3.5 \\
\hline S80_28 & 1779 & 543 & 119 & 0.31 & 0.05772 & 0.208 & 0.64240 & 0.825 & 0.08077 & 0.755 & 0.96 & 500.7 & 3.6 & 500.4 & 3.9 \\
\hline S80_29 & 1236 & 255 & 56 & 0.21 & 0.05768 & 0.260 & 0.63130 & 0.998 & 0.07 & 0.881 & 0.97 & 492.9 & 4.2 & 492.6 & 4.5 \\
\hline S80_30 & 2875 & 715 & 164 & 0.25 & 0.05829 & 0.165 & 0.66440 & 0.707 & 0.08282 & 0.712 & 0.97 & 512.9 & 3.5 & 512.5 & 3.7 \\
\hline S80_31 & 108 & 57 & 16 & 0.53 & 0.08033 & 1.145 & 0.84300 & 1.423 & 0.07608 & 0.802 & 0.51 & 472.6 & .7 & 459.1 & 3.8 \\
\hline S80_32 & 2454 & 545 & 124 & 0.22 & 0.05780 & 0.190 & 0.65340 & 0.689 & 0.08226 & 0.620 & 0.96 & 509.6 & 3.0 & 509.4 & 3.2 \\
\hline S80_33 & 400 & 200 & 45 & 0.50 & 0.05734 & 0.331 & 0.63860 & 0.861 & 0.08095 & 0.741 & 0.90 & 501.8 & 3.6 & 501.7 & 3.8 \\
\hline S80_34 & 1605 & 427 & 99 & 0.27 & 0.05765 & 0.225 & 0.67660 & 0.813 & 0.08503 & 0.764 & 0.92 & 526.1 & .9 & 526.2 & 4.1 \\
\hline S80_35 & 4620 & 826 & 0 & 0.18 & -7.08000 & -5.508 & -0.00053 & -28.302 & 0.00000 & 22.248 & -0.72 & 0.0 & 0.0 & 0.0 & 0.0 \\
\hline S80_36 & 2530 & 374 & 81 & 0.15 & 0.05771 & 0.225 & 0.66600 & 0.465 & 0.08372 & 0.442 & 0.88 & 518.3 & .2 & 518.3 & 2.4 \\
\hline S80_37 & 1289 & 351 & 84 & 0.28 & 0.05746 & 0.244 & 0.67080 & 0.537 & 0.08471 & 0.425 & 0.90 & 524.2 & 2.1 & 524.4 & 2.3 \\
\hline S80_38 & 3756 & 593 & 138 & 0.16 & 0.05824 & 0.170 & 0.65880 & 0.410 & 0.08212 & 0.329 & 0.94 & 508.8 & 1.6 & 508.3 & 1.7 \\
\hline S80_39 & 2414 & 557 & 126 & 0.23 & 0.05807 & 0.207 & 0.64740 & 0.355 & 0.08100 & 0.284 & 0.70 & 502.1 & 1.4 & 501.6 & 1.5 \\
\hline S80_40 & 1691 & 368 & 82 & 0.22 & 0.05766 & 0.208 & 0.63920 & 0.375 & 0.08044 & 0.286 & 0.89 & 498.8 & 1.4 & 498.5 & 1.5 \\
\hline$\overline{S 60 \_001}$ & 555 & 201 & 47 & 0.36 & 0.05762 & 1.305 & 0.62790 & 1.420 & 0.07858 & 0.560 & 0.80 & 487.7 & 3.6 & 487.2 & 2.8 \\
\hline S60_002 & 861 & 252 & 61 & 0.30 & 0.05719 & 1.222 & 0.63980 & 1.565 & 0.08134 & 0.977 & 0.78 & 504.1 & 3.1 & 504.2 & 5.1 \\
\hline S60_003 & 1553 & 421 & 100 & 0.28 & 0.05607 & 1.125 & 0.63010 & 1.272 & 0.08126 & 0.594 & 0.91 & 503.6 & 4.2 & 504.4 & 3.1 \\
\hline S60_004 & 963 & 311 & 74 & 0.33 & 0.05614 & 1.160 & 0.62060 & 1.288 & 0.08069 & 0.560 & 0.84 & 500.2 & 3.9 & 500.9 & 2.9 \\
\hline S60_005 & 280 & 127 & 30 & 0.46 & 0.05566 & 0.826 & 0.61290 & 1.239 & 0.08046 & 0.923 & 0.65 & 498.9 & 2.8 & 499.8 & 4.7 \\
\hline S60_006 & 191 & 80 & 19 & 0.42 & 0.05687 & 0.897 & 0.63320 & 1.046 & 0.08094 & 0.538 & 0.64 & 501.7 & 3.7 & 502.0 & 2.8 \\
\hline S60_007 & 462 & 127 & 32 & 0.28 & 0.05673 & 1.490 & 0.64150 & 1.807 & 0.08222 & 1.021 & 0.63 & 509.4 & 3.6 & 509.8 & 5.4 \\
\hline S60_008 & 969 & 282 & 66 & 0.29 & 0.05696 & 1.189 & 0.62490 & 1.312 & 0.08035 & 0.556 & 0.90 & 498.2 & 3.8 & 498.3 & 2.9 \\
\hline S60_009 & 316 & 128 & 31 & 0.41 & 0.05780 & 0.779 & 0.64700 & 0.947 & 0.08149 & 0.540 & 0.67 & 505.0 & 3.7 & 504.7 & 2.8 \\
\hline S60_010 & 547 & 198 & 48 & 0.36 & 0.05828 & 1.333 & 0.63270 & 1.671 & 0.07967 & 1.008 & 0.74 & 494.1 & 3.0 & 493.4 & 5.1 \\
\hline S60_011 & 386 & 121 & 30 & 0.31 & 0.05834 & 0.754 & 0.64700 & 1.292 & 0.08133 & 1.050 & 0.68 & 504.1 & 3.4 & 503.4 & 5.4 \\
\hline S60_012 & 274 & 124 & 31 & 0.46 & 0.05827 & 0.875 & 0.64800 & 1.304 & 0.08143 & 0.967 & 0.61 & 504.6 & 2.9 & 504.1 & 5.0 \\
\hline S60_013 & 245 & 93 & 23 & 0.38 & 0.05840 & 0.890 & 0.64730 & 1.355 & 0.08102 & 1.021 & 0.56 & 502.2 & 3.2 & 501.5 & 5.3 \\
\hline
\end{tabular}




\begin{tabular}{|c|c|c|c|c|c|c|c|c|c|c|c|c|c|c|c|}
\hline \multirow{2}{*}{$\begin{array}{c}\text { Sample } \\
\text { Name }\end{array}$} & \multicolumn{4}{|c|}{ Concentrations (ppm) } & \multicolumn{9}{|c|}{ Measured Isotopic Ratios } & \multicolumn{2}{|c|}{ measured Isotopic Age } \\
\hline & $\mathbf{P b}$ & $\mathbf{U}$ & Th & $\mathbf{T h} / \mathrm{U}$ & ${ }^{20 /} \mathrm{Pb} /{ }^{206} \mathrm{~Pb}$ & $2 \mathrm{~s} \%$ & ${ }^{20 /} \mathbf{P b} /{ }^{235} \mathbf{U}$ & $2 s \%$ & ${ }^{206} \mathrm{~Pb} /{ }^{238} \mathrm{U}$ & 2s $\%$ & Rho & ${ }^{20 \mathrm{x}} \mathrm{Pb} /{ }^{25 z} \mathrm{Th}$ & $2 s \%$ & ${ }^{208} \mathrm{~Pb} /{ }^{252} \mathrm{Th}$ & $2 \mathrm{~s}$ abs \\
\hline C-65_001 & 67 & 11820 & 51900 & 4.39 & 0.0523 & 1.86 & 0.0256 & 2.347 & 0.00355 & 1.717 & 0.68 & 0.001147 & 2.131 & 23.2 & 0.5 \\
\hline C-65 002 & 72 & 11140 & 54000 & 4.85 & 0.0507 & 1.84 & 0.0260 & 2.075 & 0.00372 & 1.424 & 0.50 & 0.001158 & 1.854 & 23.4 & 0.4 \\
\hline C-65_003 & 85 & 9800 & 63500 & 6.48 & 0.0530 & 2.08 & 0.0265 & 2.298 & 0.00362 & 1.272 & 0.43 & 0.001170 & 1.668 & 23.6 & 0.4 \\
\hline C-65_004 & 69 & 11920 & 53100 & 4.45 & 0.0487 & 1.68 & 0.0254 & 2.202 & 0.00376 & 1.277 & 0.57 & 0.001149 & 1.605 & 23.2 & 0.4 \\
\hline C-65_005 & 67 & 10430 & 49200 & 4.72 & 0.0500 & 2.20 & 0.0258 & 2.833 & 0.00369 & 1.381 & 0.51 & 0.001173 & 1.664 & 23.7 & 0.4 \\
\hline C-65_006 & 65 & 17090 & 50500 & 2.95 & 0.0490 & 1.39 & 0.0245 & 1.963 & 0.00361 & 1.496 & 0.68 & 0.001127 & 1.808 & 22.8 & 0.4 \\
\hline C-65_007 & 75 & 8560 & 56300 & 6.58 & 0.0517 & 2.32 & 0.0274 & 2.812 & 0.00383 & 1.514 & 0.55 & 0.001174 & 1.918 & 23.7 & 0.5 \\
\hline C-65_008 & 73 & 6840 & 53800 & 7.87 & 0.0528 & 2.46 & 0.0290 & 2.763 & 0.00396 & 1.414 & 0.53 & 0.001163 & 1.848 & 23.5 & 0.4 \\
\hline C-65_009 & 98 & 6280 & 64200 & 10.22 & 0.0561 & 2.14 & 0.0344 & 2.353 & 0.00447 & 1.455 & 0.47 & 0.001331 & 1.878 & 26.9 & 0.5 \\
\hline C-65_010 & 67 & 16390 & 50900 & 3.11 & 0.0495 & 1.80 & 0.0241 & 1.989 & 0.00359 & 1.423 & 0.55 & 0.001160 & 1.938 & 23.4 & 0.5 \\
\hline C-65_011 & 66 & 13050 & 50600 & 3.88 & 0.0507 & 1.70 & 0.0270 & 2.594 & 0.00384 & 1.640 & 0.71 & 0.001143 & 2.137 & 23.1 & 0.5 \\
\hline C-65_012 & 60 & 6260 & 38700 & 6.18 & 0.0535 & 2.24 & 0.0322 & 2.767 & 0.00434 & 1.497 & 0.54 & 0.001351 & 1.928 & 27.3 & 0.5 \\
\hline C-65_013 & 62 & 16270 & 46500 & 2.86 & 0.0499 & 1.74 & 0.0247 & 2.106 & 0.00355 & 1.154 & 0.51 & 0.001164 & 1.503 & 23.5 & 0.4 \\
\hline C-65_014 & 74 & 7410 & 55300 & 7.46 & 0.0528 & 2.08 & 0.0290 & 2.931 & 0.00395 & 1.316 & 0.60 & 0.001157 & 1.769 & 23.4 & 0.4 \\
\hline C-65_015 & 87 & 9290 & 65000 & 7.00 & 0.0532 & 2.07 & 0.0269 & 2.643 & 0.00364 & 1.319 & 0.63 & 0.001161 & 1.764 & 23.5 & 0.4 \\
\hline C-65_016 & 76 & 11570 & 56100 & 4.85 & 0.0498 & 1.73 & 0.0256 & 2.113 & 0.00376 & 1.488 & 0.67 & 0.001181 & 1.993 & 23.9 & 0.5 \\
\hline C-65_017 & 78 & 8720 & 58700 & 6.73 & 0.0508 & 1.97 & 0.0272 & 2.461 & 0.00388 & 1.496 & 0.52 & 0.001163 & 1.762 & 23.5 & 0.4 \\
\hline C-65_018 & 70 & 13740 & 52800 & 3.84 & 0.0507 & 1.40 & 0.0252 & 2.107 & 0.00364 & 1.677 & 0.66 & 0.001175 & 1.917 & 23.7 & 0.5 \\
\hline C-65_019 & 68 & 15350 & 51600 & 3.36 & 0.0500 & 1.44 & 0.0245 & 2.166 & 0.00358 & 1.958 & 0.71 & 0.001153 & 2.121 & 23.3 & 0.5 \\
\hline C-65_020 & 64 & 9580 & 47700 & 4.98 & 0.0499 & 2.20 & 0.0258 & 2.250 & 0.00379 & 1.372 & 0.50 & 0.001170 & 1.838 & 23.6 & 0.4 \\
\hline C-65_021 & 77 & 17120 & 57500 & 3.36 & 0.0501 & 1.70 & 0.0244 & 2.414 & 0.00356 & 1.545 & 0.70 & 0.001155 & 1.772 & 23.3 & 0.4 \\
\hline C-65_022 & 67 & 8700 & 49500 & 5.69 & 0.0514 & 2.33 & 0.0271 & 3.026 & 0.00375 & 1.815 & 0.59 & 0.001161 & 2.195 & 23.5 & 0.5 \\
\hline C-65_023 & 64 & 15630 & 48300 & 3.09 & 0.0483 & 1.47 & 0.0244 & 2.299 & 0.00368 & 1.551 & 0.71 & 0.001169 & 2.096 & 23.6 & 0.5 \\
\hline C-65_024 & 69 & 8740 & 50600 & 5.79 & 0.0516 & 2.33 & 0.0266 & 2.972 & 0.00371 & 1.781 & 0.64 & 0.001179 & 2.336 & 23.8 & 0.6 \\
\hline C-65_025 & 64 & 7540 & 46080 & 6.11 & 0.0511 & 2.54 & 0.0266 & 2.783 & 0.00381 & 1.705 & 0.53 & 0.001210 & 2.283 & 24.4 & 0.6 \\
\hline C-65_026 & 71 & 10850 & 52300 & 4.82 & 0.0503 & 2.19 & 0.0265 & 3.014 & 0.00383 & 1.595 & 0.65 & 0.001188 & 2.236 & 24.0 & 0.5 \\
\hline C-65_027 & 72 & 8310 & 52700 & 6.34 & 0.0523 & 1.91 & 0.0286 & 2.410 & 0.00394 & 1.421 & 0.47 & 0.001180 & 1.741 & 23.8 & 0.4 \\
\hline C-65_028 & 64 & 14030 & 47500 & 3.39 & 0.0492 & 1.56 & 0.0247 & 2.230 & 0.00362 & 1.739 & 0.69 & 0.001167 & 2.271 & 23.6 & 0.5 \\
\hline C-65_029 & 77 & 8730 & 57600 & 6.60 & 0.0502 & 2.19 & 0.0257 & 2.721 & 0.00374 & 1.497 & 0.59 & 0.001183 & 2.244 & 23.9 & 0.5 \\
\hline C-65_030 & 60 & 14030 & 44270 & 3.16 & 0.0498 & 1.79 & 0.0272 & 2.425 & 0.00397 & 1.536 & 0.65 & 0.001167 & 1.928 & 23.6 & 0.5 \\
\hline C-65_032 & 64 & 10060 & 47800 & 4.75 & 0.0497 & 2.21 & 0.0257 & 2.806 & 0.00374 & 1.525 & 0.59 & 0.001175 & 1.917 & 23.7 & 0.5 \\
\hline C-65_033 & 71 & 11870 & 53100 & 4.47 & 0.0492 & 1.69 & 0.0256 & 2.269 & 0.00373 & 1.581 & 0.66 & 0.001170 & 1.924 & 23.6 & 0.5 \\
\hline C-65_034 & 76 & 12010 & 57200 & 4.76 & 0.0475 & 1.81 & 0.0247 & 2.634 & 0.00380 & 1.606 & 0.79 & 0.001151 & 2.125 & 23.2 & 0.5 \\
\hline C-65_035 & 67 & 13660 & 50200 & 3.67 & 0.0509 & 1.67 & 0.0253 & 2.213 & 0.00359 & 1.391 & 0.64 & 0.001165 & 1.845 & 23.5 & 0.4 \\
\hline C-65_036 & 66 & 15700 & 48900 & 3.11 & 0.0499 & 1.42 & 0.0250 & 2.201 & 0.00363 & 1.542 & 0.79 & 0.001178 & 1.828 & 23.8 & 0.4 \\
\hline C-65_037 & 67 & 7930 & 49600 & 6.25 & 0.0492 & 2.24 & 0.0258 & 2.825 & 0.00384 & 1.799 & 0.54 & 0.001181 & 2.078 & 23.9 & 0.5 \\
\hline C-65_038 & 65 & 14510 & 49700 & 3.43 & 0.0487 & 1.50 & 0.0240 & 2.039 & 0.00353 & 1.388 & 0.63 & 0.001144 & 1.961 & 23.1 & 0.5 \\
\hline C-65_039 & 75 & 13340 & 54700 & 4.10 & 0.0510 & 1.88 & 0.0253 & 2.137 & 0.00364 & 1.539 & 0.50 & 0.001181 & 1.824 & 23.9 & 0.4 \\
\hline
\end{tabular}

